\title{
Trichoderma atroviride como controlador biológico de fusariosis de espiga de trigo mediante la reducción del inóculo primario en rastrojo Trichoderma atroviride as a biocontrol agent of Fusarium head blight by reducing the inoculum of the pathogen in wheat straw
}

\author{
Mónica Cabrera $^{1}$ (D), Gabriela Garmendia ${ }^{1}$ (D), Caterina Rufo ${ }^{2}$ (D), \\ Silvia Pereyra ${ }^{3}$ y Silvana Vero $^{1:}$ (iD
}

\footnotetext{
${ }^{1}$ Área Microbiología. Departamento de Biociencias, Facultad de Química. Universidad de la República. Gral. Flores 2124. 11800 Montevideo, Uruguay. * Autora para correspondencia / Corresponding author (svero@fq.edu.uy)

${ }^{2}$ Alimentos y Nutrición, Instituto Polo Tecnológico, Facultad de Química, Universidad de la República. By Pass Ruta 8 s/n. 91000 Pando, Canelones, Uruguay.

${ }^{3}$ Instituto Nacional de Investigación Agropecuaria (INIA). INIA La Estanzuela. 70000 Colonia, Uruguay.
}

\section{RESUMEN}

La fusariosis de la espiga (FE) es una enfermedad que causa grandes pérdidas de rendimiento $\mathrm{y}$ calidad en granos de trigo a nivel mundial. Es producida principalmente por hongos del complejo Fusarium graminearum, los cuales en su mayoría producen micotoxinas que contaminan los granos afectados. El inóculo primario de la enfermedad proviene de los rastrojos del cultivo del año anterior. En condiciones ambientales adecuadas ascosporas o conidias del patógeno infectan las flores que constituyen el órgano susceptible de la planta. Las medidas de control incluyen prácticas culturales y aplicación de fungicidas. Sin embargo, ninguna práctica es por sí sola totalmente efectiva. En este contexto el uso de control biológico surge como una medida complementaria. El objetivo de este trabajo consistió en aislar y seleccionar cepas nativas de Trichoderma spp. para el control del inóculo primario de $\mathrm{FE}$ en trigo. Se trabajó con 16 cepas de Trichoderma identificadas a nivel de especie las cuales exhibieron una o varias actividades que podrían relacionarse con su potencial como agente de biocontrol. Una de las cepas identificada como T. atroviride, fue seleccionada con base en su habilidad para inhibir la formación de peritecios por parte del patógeno sobre rastrojo de trigo y su capacidad de producción de enzimas asociadas a la degradación del rastrojo que sirve de soporte al patógeno.

Cita recomendada / Recommended citation:

Cabrera, M., G. Garmendia, C. Rufo, S. Pereyra y S. Vero. 2020. Trichoderma atroviride como controlador biológico de fusariosis de espiga de trigo mediante la reducción del inóculo primario en rastrojo. Terra Latinoamericana Número Especial 38-3: 629-651.

DOI: https://doi.org/10.28940/terra.v38i3.664

\section{SUMMARY}

Fusarium head blight (FHB) is the principal disease affecting wheat worldwide, decreasing grain quality, and production. This disease is mainly caused by members of the Fusarium graminearum species complex (FGSC), which have the capability to produce mycotoxins in the contaminated grains. The pathogen overwinters on crop residues (wheat straw). Under adequate climate conditions, the pathogen conidia or ascospores infect wheat flowers, which are the susceptible part of the plant. To minimize disease incidence, cultural practices and fungicide treatments are recommended, but none of them are effective by themselves. In that sense, biological control appears to be an alternative strategy. Therefore, the aim of this study was to isolate and select native Trichoderma spp. strains for FHB control in wheat. Sixteen isolates were identified at species level. All of them showed at least one characteristic that could be associated to their potential ability as biological control agents. An isolate identified as $T$. atroviride was selected according to its ability to inhibit $F$. graminearum perithecium development on wheat straw and produce enzymes associated to wheat straw degradation, which is the pathogen physical support.

Index words: biocontrol, Fusarium graminearum. 
Palabras clave: biocontrol, Fusarium graminearum.

\section{INTRODUCCIÓN}

La fusariosis de la espiga (FE) es una enfermedad que causa grandes pérdidas de rendimiento y calidad en granos de trigo a nivel mundial (Casa et al., 2004). Es producida principalmente por hongos pertenecientes al complejo Fusarium graminearum el cual está formado por 16 especies. En Uruguay, al igual que en los países productores de trigo de la región, Fusarium graminearum sensu stricto es la especie predominante (Umpiérrez et al., 2013). Los hongos de esta especie son capaces de producir micotoxinas en los granos, siendo el deoxinivalenol (DON) la toxina más frecuentemente producida en trigo (Edwards et al., 2001). El consumo de granos contaminados con DON tiene como efecto la aparición de trastornos digestivos (vómitos, diarrea), e incluso puede afectar la síntesis de proteínas o provocar deficiencias del sistema inmunológico en los animales llevando a pérdidas de peso (Pestka y Smolinski, 2005). Por ello, se maximizan esfuerzos en el control de la fusariosis en cereales de forma de disminuir pérdidas productivas y evitar problemas de salud ocasionados por el consumo de granos o productos derivados contaminados.

El ciclo de la fusariosis de espiga comienza con el inóculo primario del patógeno que se desarrolla en los rastrojos de la cosecha anterior. En condiciones apropiadas de temperatura y humedad las ascosporas provenientes de los peritecios y eventualmente los conidios del patógeno producidos en el rastrojo, pueden alcanzar las anteras de las flores de trigo (órgano susceptible) de la nueva cosecha y causar infección. La siembra sin laboreo, práctica común en la región, propicia la sobrevivencia saprofítica del patógeno sobre los rastrojos y, por tanto, favorece el desarrollo de la enfermedad (Inch y Gilbert, 2003).

La FE es actualmente una de las enfermedades que presenta más desafíos para su control. Ninguna práctica es por sí sola efectiva $\mathrm{y}$, por lo tanto, es importante adoptar todas las medidas de control disponibles tanto culturales, químicas o biológicas que puedan contribuir a disminuir la incidencia de la enfermedad (Pereyra, 2003). Una práctica cultural que contribuye a la prevención de la enfermedad es intercalar en el tiempo cultivos de cereales con otros no susceptibles como oleaginosas o leguminosas,

\section{INTRODUCTION}

Fusarium head blight (FHB) is a disease that has caused great losses in wheat grain yield and quality at world level (Casa et al., 2004). It is produced mainly by fungi that belong to the Fusarium graminearum species complex, formed by 16 species. In Uruguay, same as in other wheat-producing countries in the region, Fusarium graminearum sensu stricto is the predominant species (Umpiérrez et al., 2013). The fungi of this species are capable of producing mycotoxins in grains, of which deoxynivalenol (DON) is the most frequently produced in wheat (Edwards et al., 2001). Consumption of grains contaminated with DON may cause digestive disorders (vomiting, diarrhea), alterations in protein synthesis or deficiencies on the immunological system in animals, leading to weight loss (Pestka and Smolinski, 2005). Thus, efforts to control FHB in cereals should be maximized to decrease productive losses and avoid health problems caused by the consumption of contaminated grains or grain-derived products.

The FHB cycle in wheat starts with the primary pathogen inoculum that develops on wheat straw of the previous harvest. In the appropriate temperature and humidity conditions, the ascospores coming from perithecia - and eventually the pathogen conidia produced on wheat straw - may reach the wheat flower anthers (susceptible organ) of the new crop and cause infection. Sowing without tilling - a common practice in the region - favors the pathogen saprophytic survival on wheat straw, thus, favoring disease development (Inch and Gilbert, 2003).

The FHB is currently one of the diseases that has shown more challenges for its control. No practice is effective on its own, so it is important to adopt all the available control measurements both cultural, chemical or biological that may contribute to decrease disease incidence (Pereyra, 2003). One cultural practice that contributes to disease prevention is alternating in time cereal cultivations with other not susceptible crops, such as oilseed or leguminous plants to minimize the inoculum (Dill-Macky and Jones, 2000). At the same time, the use of wheat varieties with less sensitivity to FHB is another control option since no completely resistant variety exists to date (Mazzilli et al., 2011). Disease management also includes chemical control by 
para de esta forma minimizar el inóculo (Dill-Macky y Jones, 2000). A su vez, el uso de variedades de trigo con menor sensibilidad a la FE es otra de las opciones de control, ya que hasta el momento no existen variedades completamente resistentes (Mazzilli et al., 2011). El manejo de la enfermedad incluye también el control químico mediante aplicación de fungicidas, como por ejemplo triazoles, al inicio de floración para impedir la infección de la planta (Amarasinghe et al., 2013). Sin embargo, la efectividad del control químico depende del momento y del método de aplicación, así como de la susceptibilidad de la población del patógeno que se busca controlar. En este contexto el control biológico, se presenta como una opción complementaria para reducir la incidencia y severidad de la enfermedad. Si bien no existe hasta el momento ningún producto comercial para la FE, el desarrollo en la investigación a nivel mundial es amplio y ha demostrado la posibilidad del uso de agentes microbianos para complementar el control de esta enfermedad (Schisler et al., 2002). En función de la biología de la enfermedad, existirían dos estrategias de biocontrol para disminuir los riesgos de infección. La primera tendría como objetivo disminuir el inóculo primario aplicando el biocontrolador sobre el rastrojo del cultivo anterior. La segunda se enfocaría en proteger el sitio de infección (la flor), para lo cual el agente de biocontrol debería aplicarse al inicio de la floración, de forma de impedir o minimizar la infección de la planta (Palazzini et al., 2018). En el primer caso, los antagonistas deberían ser buenos colonizadores de rastrojo, de forma tal que sean capaces de desarrollarse en el sitio de acción, impidiendo la colonización del patógeno y la propagación del inóculo primario (Villar et al., 2019). En ese sentido se han publicado trabajos basados en el uso de Trichoderma harzianum (Inch y Gilbert, 2007), Trichoderma gamsii (Matarese et al., 2012) o Microsphaeropsis spp. (Bujold et al., 2001) como controladores biológicos de $F$. graminearum en rastrojo de trigo. La capacidad del agente de biocontrol de sobrevivir y desarrollarse en los rastrojos en las condiciones ambientales del lugar sería fundamental para llevar a cabo esta estrategia de control, por lo cual el desarrollo de cepas antagonistas locales adquiere relevancia.

El objetivo del presente trabajo consistió en aislar y seleccionar cepas nativas de Trichoderma spp. para el control del inóculo primario de FE en trigo. applying fungicide, for example, triazole, at the start of flowering to avoid plant infection (Amarasinghe et al., 2013). Nonetheless, the effectiveness of chemical control depends on the moment and method of application, as well as the susceptibility of the pathogen population to be controlled. In this context, biological control comes to be a supplementary option to reduce disease incidence and severity. Even though no commercial product has been found until now for FHB, research development at world level has been extensive and shown the possibility of using microbial agents to supplement this disease control (Schisler et al., 2002). In function of the disease biology, two biocontrol strategies exist to decrease infection risks. The first one has as its objective to decrease the primary inoculum by applying a biocontrol agent on wheat straw of the previous crop. The second one focuses on protecting the infection site (the flower), and in this case, the biocontrol agent should be applied at the start of flowering to avoid or minimize plant infection (Palazzini et al., 2018). In the first case, the antagonists should colonize effectively wheat straw, in such a way that they can develop in the site of action, avoiding pathogen colonization and the propagation of the primary inoculum (Villar et al., 2019). In this sense, studies on the use of Trichoderma harzianum (Inch and Gilbert, 2007), Trichoderma gamsii (Matarese et al., 2012) or Microsphaeropsis spp. (Bujold et al., 2001 ) as biocontrol agents of $F$. graminearum on wheat straw have been previously published. The capacity of the biocontrol agent to survive and develop in wheat straw in the local environmental conditions would be fundamental to perform the control strategy. In that sense, the development of local antagonist strains have acquired relevance.

Therefore, the objective of this research study consisted of isolating and selecting native strains of Trichoderma spp. for the control of the primary FHB inoculum in wheat.

\section{MATERIALS AND METHODS}

\section{Pathogen}

The Fusarium graminearum F224a used in this study belongs to the Microbial Culture Collection 


\section{MATERIALES Y MÉTODOS}

\section{Patógeno}

La cepa $F$. graminearum $\mathrm{F} 224 \mathrm{a}$, perteneciente a la colección de microorganismos de la Cátedra de Microbiología de la Facultad de Química, Udelar, fue seleccionada como patógeno para este estudio con base a los elevados niveles de deoxinivalenol producidos en cultivo, a la capacidad de producir peritecios en rastrojo de trigo en condiciones controladas (humedad y temperatura), y a los niveles de agresividad al ser inoculada en anteras de flores de trigo en ensayos en invernáculo (Umpiérrez et al., 2013).

\section{Aislamiento de Antagonistas}

Las cepas de Trichoderma spp. utilizadas en este trabajo se aislaron de 20 muestras de rastrojo de trigo provenientes de la principal zona de producción de nuestro país localizada al este del río Uruguay, en los departamentos de Río Negro, Soriano y Colonia. Para ello, $10 \mathrm{~g}$ de rastrojo se colocaron en $100 \mathrm{~mL}$ de suero fisiológico estéril y se homogeneizaron en Stomacher $400^{\circledR}$ (Stomacher, UK) durante $2 \mathrm{~min}$ a máxima velocidad. Diluciones de esta suspensión fueron sembradas en superficie en placas de Potato Dextrose Agar (PDA, Oxoid) conteniendo neomicina (50 $\mathrm{mg} \mathrm{mL}^{-1}$ ). Las colonias típicas de Trichoderma spp. fueron reaisladas en placas de PDA, y posteriormente se realizaron cultivos monospóricos a partir de las mismas. Los aislamientos obtenidos fueron conservados en tubos de PDA inclinado a $5{ }^{\circ} \mathrm{C}$ hasta su uso.

\section{Identificación de Antagonistas}

Las cepas de Trichoderma fueron identificadas mediante el estudio de las secuencias de dos regiones génicas (ITS1-ITS2 y tef1 $\alpha$ ). En primer lugar, se realizó la extracción y purificación del ADN de cada cepa y a partir del ADN total se amplificó la región intergénica ITS1-ITS2 y una parte del gen que codifica para el factor de elongación de la traducción 1 alfa (tef $1 \alpha$ ), que comprende la totalidad del cuarto intrón y parte del cuarto y quinto exón del gen (Jaklitsch y Voglmayr, 2015). El ADN de cada cepa se extrajo según Garmendia y Vero (2016). A partir del ADN se realizaron las reacciones de amplificación en un of the Área Microbiología, Facultad de Química, at Universidad de la República (UDELAR), Montevideo, Uruguay. It was selected based on the elevated levels of deoxynivalenol (DON) produced in culture, its capacity of generating perithecia in wheat straw in controlled (humidity and temperature) conditions, and the high aggressiveness level when inoculated in wheat flower anthers in greenhouse assays (Umpiérrez et al., 2013).

\section{Antagonist Isolation}

Trichoderma spp. strains utilized in this study were isolated from 20 wheat straw samples from the main production zone in our country located eastward from Rio Uruguay in the departments of Río Negro, Soriano, and Colonia. For this purpose, $10 \mathrm{~g}$ of wheat straw were placed in $100 \mathrm{~mL}$ of sterile physiological serum and homogenized in Stomacher $400^{\circledR}$ (Stomacher, UK) for two min at maximum speed. Dilutions of this suspension were sown on surface Potato Dextrose Agar (PDA, Oxoid) Petri dishes containing neomycin (50 $\left.\mathrm{mg} \mathrm{mL}^{-1}\right)$. Typical colonies of Trichoderma spp. were cultured in PDA Petri dishes; subsequently, monosporic cultures were performed, and the isolates obtained were preserved in PDA test tubes at $5{ }^{\circ} \mathrm{C}$ until use.

\section{Antagonist Identification}

Trichoderma strains were identified by studying the sequences of two genomic regions, ITS1-ITS2 and one part of the gene codifying for the translational elongation factor 1 alpha (tefl $\alpha$ ) comprising the totality of intron 4 and part of the exons 4 and 5 of the gene (Jaklitsch and Voglmayr, 2015). DNA extraction was carried out according to Garmendia and Vero (2016). The amplification reactions were performed in a total volume of $25 \mu \mathrm{L}$ utilizing $0.2 \mu \mathrm{L}$ of each primer $25 \mu \mathrm{M}, 0.15 \mathrm{U}$ of Taq polymerase (Invitrogen, Thermo Fisher Scientific, Waltham MA, USA), $0.75 \mu \mathrm{L}$ of $\mathrm{MgCl}_{2} 50 \mathrm{mM}, 1 \mu \mathrm{L}$ of each dNTP $5 \mathrm{mM}$ solution (Invitrogen, Thermo Fisher Scientific, Waltham MA, USA), $2.5 \mu \mathrm{L}$ of amplification buffer (Invitrogen, Thermo Fisher Scientific, Waltham MA, USA), and approximately $20 \mathrm{ng}$ of DNA, completing the reaction volume with sterile distilled water. In the case of the ITS1-ITS2 region amplification, the primers used were ITS1 (5'-TCCCGGTTCGCTCGCCGTTACTA-3') and 
volumen total de $25 \mu \mathrm{L}$ utilizando $0.2 \mu \mathrm{L}$ de cada primer $25 \mu \mathrm{M}, 0.15 \mathrm{U}$ de Taq polimerasa (Invitrogen), $0.75 \mu \mathrm{L}$ de $\mathrm{MgCl}_{2} 50 \mathrm{mM}, 1 \mu \mathrm{L}$ de cada solución de dNTP $5 \mathrm{mM}$ (Invitrogen), $2.5 \mu \mathrm{L}$ de buffer de amplificación (Invitrogen), aproximadamente $20 \mathrm{ng}$ de ADN, completando el volumen de reacción con agua destilada estéril. En el caso de la amplificación de la región ITS1-ITS2 se utilizaron los cebadores ITS1 (5'-TCCCGGTTCGCTCGCCGTTACTA-3') e ITS4 (5'-TCCTCCCGCTTATTGATATGC-3') (White et al., 1990). La mezcla de reacción fue sometida a $5 \mathrm{~min}$ de desnaturalización a $95^{\circ} \mathrm{C}$, seguida de 35 ciclos de $1 \mathrm{~min}$ de desnaturalización a $95^{\circ} \mathrm{C}, 30 \mathrm{seg}$ de alineamiento a $55^{\circ} \mathrm{C}, 1$ min de extensión a $72{ }^{\circ} \mathrm{C}$, para finalizar con una extensión de $10 \mathrm{~min}$ a $72{ }^{\circ} \mathrm{C}$.

Para el gen tef $1 \alpha$, los cebadores utilizados fueron EF1-728F (5'-CATCGAGAAGTTCGAGAAGG-3') (Carbone y Kohn, 1999) y Tef1 rev (5'-GCCATCCTTGGAGATACCAGC-3') (Samuels et al., 2006). El ciclo de PCR fue igual al anterior excepto la temperatura de alineamiento la cual fue de $51{ }^{\circ} \mathrm{C}$. Los cebadores utilizados en ambos casos fueron sintetizados por Byo Synthesis Company (Lewisvile, TX). Los productos de PCR fueron analizados en gel de agarosa al $0.8 \%$ conteniendo bromuro de etidio $\left(5 \mu \mathrm{g} \mathrm{mL}^{-1}\right)$ obteniéndose una banda de alrededor de 600 pares de bases. Los productos de amplificación de ambas regiones fueron purificados y secuenciados por Macrogen Inc. (Seúl, Corea). Las secuencias de ambas regiones fueron comparadas con las depositadas en la base de datos Genbank (https://www.ncbi.nlm.nih.gov/ genbank/), utilizando la herramienta BLAST.

\section{Análisis Filogenético}

Se realizó el análisis filogenético de las secuencias concatenadas (ITS1-ITS2 y gen tef $1 \alpha$ ) alineándolas con secuencias concatenadas de cepas tipo, las cuales se obtuvieron del GenBank. Las secuencias se alinearon usando el programa MEGA versión 6 (Tamura et al., 2013). Los árboles filogenéticos se construyeron por Neighbor-Joining (Saitou y Nei, 1987) y las distancias evolutivas fueron computadas con el método de JukesCantor (Jukes y Cantor, 1969). Todas las posiciones conteniendo gaps o datos faltantes fueron eliminadas con la opción de comparación pareada de secuencias (Pairwise deletion option). La estabilidad de los grupos fue determinada utilizando un bootstrap de 1000 réplicas (Felsenstein, 1985).
ITS4 (5'-TCCTCCCGCTTATTGATATGC-3') (White et al., 1990). The reaction mixture was subjected to 5 min denaturation at $95{ }^{\circ} \mathrm{C}$, followed by 35 cycles of one-min denaturation at $95{ }^{\circ} \mathrm{C} ; 30 \mathrm{sec}$ alignment at $55^{\circ} \mathrm{C}$; one min extension at $72{ }^{\circ} \mathrm{C}$, ending with a 10 min extension at $72{ }^{\circ} \mathrm{C}$.

In the case of the tefl $\alpha$ gene, the primers used were EF1-728F (5'-CATCGAGAAGTTCGAGAAGG-3') (Carbone and Kohn, 1999) and Tef1 rev (5'-GCCATCCTTGGAGATACCAGC-3') (Samuels et al., 2006). The PCR cycle was similar to the previous one except for the annealing temperature, which was $51{ }^{\circ} \mathrm{C}$. The primers used in both cases were synthetized by Byo Synthesis Company (Lewisville, TX, USA). The PCR products were analyzed in agarose gel at $0.8 \%$ containing ethidium bromide $\left(5 \mu \mathrm{g} \mathrm{mL} \mathrm{m}^{-1}\right)$. A band of around 600 base pairs was obtained. The amplification products of both regions were purified and sequenced by Macrogen Inc. (Seoul, Korea). The sequences of both regions were compared with those deposited in Genbank (https://www.ncbi.nlm.nih.gov/ genbank/) database using the BLAST tool.

\section{Phylogenetic Analyses}

The phylogenetic analyses of the concatenated sequences (ITS1-ITS2 and tef1 $\alpha$ gene) were aligned with the concatenated sequences of type strains obtained by GenBankusing MEGA program version 6 (Tamura et al., 2013). The phylogenetic trees were constructed by the Neighbor-Joining (Saitou and Nei, 1987) method, and the evolutionary distances were computed by the Jukes-Cantor (Jukes and Cantor, 1969) model. All the positions containing gaps or missing data were eliminated with the option of pairedsequence comparison (Pairwise deletion option). Group stability was determined using a bootstrap of 1000 replicates (Felsenstein, 1985).

\section{Characterization of Trichoderma Strains}

Sensitivity to tebuconazole. The minimum inhibitory concentration (MIC) of the fungicide - defined as the lowest concentration that prevented visible growth of each Trichoderma strain - was determined. For this purpose, the fungicide Folicur $450^{\circledR}$ (Bayer Crop Science, Monheim am Rhein, DE) was diluted in sterile water and incorporated into PDA to achieve concentrations of $0,2,4,8,16,32$, and $64 \mathrm{mg} \mathrm{L}^{-1}$ 


\section{Caracterización de las Cepas de Trichoderma}

Sensibilidad al fungicida tebuconazol. Se determinó la mínima concentración de fungicida capaz de inhibir el crecimiento del hongo (CIM). Para ello se prepararon placas de PDA con 0, 2, 4, 8, 16, 32 y $64 \mathrm{mg} \mathrm{L}^{-1}$ de tebuconazol (Folicur $450^{\circledR}$ Bayer Crop Science), incorporado en el medio de cultivo (Umpiérrez et al., 2013). Sobre las placas se inocularon en forma puntual $5 \mu \mathrm{L}$ de suspensión de conidios de las cepas a estudiar ajustadas a una concentración de $1 \times 10^{5}$ conidios $\mathrm{mL}^{-1}$. Se sembraron ocho cepas por placa y se realizaron dos repeticiones por tratamiento. Las placas se incubaron en estufa a $25^{\circ} \mathrm{C}$ durante 5 días, evaluándose en forma visual presencia o ausencia de crecimiento, en cada uno de los tratamientos.

Determinación de la capacidad de producción de xilanasas. Para cada cepa de Trichoderma spp. se determinó la capacidad de producir xilanasas en medio mínimo con xilano como fuente de carbono. Se realizaron cultivos en medio líquido Yeast Nitrogen Base (YNB) (BioChemica, Sigma), adicionado con xilano al $0.5 \%$ como única fuente de carbono. Cada matraz conteniendo $40 \mathrm{~mL}$ de medio de cultivo se inoculó con $100 \mu \mathrm{L}$ de una suspensión de conidios de la cepa a estudiar de $2 \times 10^{4}$ conidios $\mathrm{mL}^{-1}$ y se incubó en estufa a $25^{\circ} \mathrm{C}$.

La determinación de la actividad enzimática se realizó sobre una mezcla de $100 \mu \mathrm{L}$ de buffer citratofosfato ( $\mathrm{pH}$ 5.6), $50 \mu \mathrm{L}$ de sobrenadante del cultivo (centrifugado y filtrado a través de un filtro de $0.45 \mu \mathrm{m}$ de poro) y $50 \mu \mathrm{L}$ de xilano al $1 \%$ en agua destilada. La mezcla se incubó en baño de agua a $40{ }^{\circ} \mathrm{C}$ durante 1 hora, luego se agregaron $300 \mu \mathrm{L}$ de ácido dinitrosalicílico (DNS) y se calentó en baño de agua a ebullición durante 5 minutos. Finalmente se agregaron $500 \mu \mathrm{L}$ de agua destilada y se midió la absorbancia a $540 \mathrm{~nm}$ contra cada blanco, preparado de igual manera que la mezcla de reacción, pero sin realizar incubación. En cada blanco el agregado el DNS y el calentamiento se realizaron inmediatamente después de obtener la mezcla. Cada reacción se realizó por triplicado. Una unidad de enzima fue definida como la cantidad que libera $1 \mu \mathrm{mol}$ de azúcares reductores (expresada en equivalentes de glucosa) por minuto, en las condiciones de reacción.

Producción de quitinasas asociadas a la degradación de paredes de hongos. Se evaluó la capacidad de producción de quitinasas por cada cepa de Trichoderma of tebuconazole (Umpiérrez et al., 2013). In timely manner, $5 \mu \mathrm{L}$ of conidial suspension adjusted to a concentration of $1 \times 10^{5}$ conidium $\mathrm{mL}^{-1}$ of each Trichoderma strain were inoculated on the surface of fungicide amended PDA plates Eight strains were inoculated per dish, and two replicates per treatment were performed. The Petri dishes were incubated at $25{ }^{\circ} \mathrm{C}$ for five days. Fungal growth was evaluated visually.

Determination of xylanase production capacity. For each Trichoderma spp. strain, the capacity of producing xylanase was determined in minimal medium containing xylan as carbon source. Cultures were performed in liquid Yeast Nitrogen Base (YNB) (BioChemica, Sigma Chemical, St. Louis MO, USA) medium amended with Xylan (Sigma Chemical, St. Louis, MO, USA) at $0.5 \%$ as the only carbon source. Each $40 \mathrm{~mL}$ Erlenmeyer flasks with culture medium were inoculated with $100 \mu \mathrm{L}$ of conidial suspension $\left(2 \times 10^{4}\right.$ conidia $\left.\mathrm{mL}^{-1}\right)$ of one of the strains and incubated at $25^{\circ} \mathrm{C}$.

Enzymatic activity was determined by mixing $100 \mu \mathrm{L}$ of citrate-phosphate buffer ( $\mathrm{pH} 5.6$ ), $50 \mu \mathrm{L}$ of culture supernatant (centrifuged and filtered through a $0.45 \mu \mathrm{m}$ pore filter), and $50 \mu \mathrm{L}$ of xylan at $1 \%$ in distilled water. The mixture was incubated in water bath at $40{ }^{\circ} \mathrm{C}$ for one hour; subsequently, $300 \mu \mathrm{L}$ of dinitrosalicylic acid (DNS) were added and heated in water bath to boil for five min. Finally, $500 \mu \mathrm{L}$ of distilled water were added, and absorbance was measured at $540 \mathrm{~nm}$ against each blank, which was prepared similarly to the reaction mixture but adding the DNS and heating immediately after the mixture was prepared. Each reaction was performed in triplicate. One unit of enzyme was defined as the amount released by $1 \mu \mathrm{mol}$ of reducing sugar (expressed in glucose equivalent) per minute in the reaction conditions.

Production of chitinases associated to fungal cell wall degradation. The capacity of producing chitinases by Trichoderma spp. strains was evaluated in YNB amended with fungal cell walls of $F$. graminearum in a concentration of $0.5 \%(\mathrm{~m} / \mathrm{v})$ as the only carbon source (Vero et al., 2013). The cultures were performed individually by inoculating $100 \mu \mathrm{L}$ of a suspension of $2 \times 10^{4}$ conidia $\mathrm{mL}^{-1}$ of each Trichoderma spp. strain in Erlenmeyer $200 \mathrm{~mL}$ flasks containing $40 \mathrm{~mL}$ of the medium. Incubation was performed at $25{ }^{\circ} \mathrm{C}$ without agitation for 10 days. Each culture was performed in triplicate. Once incubation ended, each culture was 
spp. al crecer en YNB adicionado con paredes celulares de $F$. graminearum en una concentración de $0.5 \%(\mathrm{~m} / \mathrm{v})$ como única fuente de carbono (Vero et al., 2013). Los cultivos se realizaron inoculando en forma individual $100 \mu \mathrm{L}$ de una suspensión de $2 \times 10^{4}$ conidios $\mathrm{mL}^{-1}$ de cada cepa de Trichoderma spp. en matraces de $200 \mathrm{~mL}$ conteniendo $40 \mathrm{~mL}$ del medio. La incubación se realizó durante 10 días a $25^{\circ} \mathrm{C}$, sin agitación. Cada cultivo se realizó por triplicado. Una vez finalizada la incubación, cada cultivo se centrifugó y el sobrenadante fue filtrado a través de un filtro de acetato de celulosa de $0.45 \mu \mathrm{m}$ de poro.

A partir del filtrado del cultivo de las distintas cepas de Trichoderma spp. se realizó la medida de la actividad quitinolítica según el método de Mahadevan y Crawford (1997) con algunas modificaciones. En pocillos de una placa de microtitulación de fondo plano se colocaron $90 \mu \mathrm{L}$ de filtrado de cultivo y $10 \mu \mathrm{L}$ de solución $0.18 \mathrm{mM}$ de p-nitrofenil-N-Acetil- $\beta$-D-Glucosamidina (Sigma, St. Louis, MO) disuelto en tampón fosfato de potasio $50 \mathrm{mM}, \mathrm{pH}$ 6.1. La placa se incubó a $25^{\circ} \mathrm{C}$ durante $24 \mathrm{~h}$ sin agitación y la reacción se finalizó con el agregado de $10 \mu \mathrm{L}$ de $\mathrm{NaOH} 1 \mathrm{M}$. Se determinó la absorbancia a $405 \mathrm{~nm}$ en un lector automático Microplate Autoreader (Bio-tek Instruments,Winooski,VT), contra un blanco de cada muestra en el que se agregó la solución de $\mathrm{NaOH}$ previo a la incubación. La concentración de paranitrofenol obtenido en cada hidrólisis se determinó mediante curva estándar Se definió una unidad de enzima como la cantidad necesaria para liberar un micromol de paranitrofenol en un minuto. El ensayo se realizó por triplicado para cada cepa.

Producción de compuestos antifúngicos volátiles. La producción de compuestos antifúngicos volátiles fue analizada según Arrarte et al. (2017), con modificaciones. Placas de PDA fueron inoculadas centralmente con un disco de agar de cinco $\mathrm{mm}$ de cada cepa de Trichoderma, proveniente de un cultivo de $48 \mathrm{~h}$ de crecimiento. En otras placas de PDA se sembró centralmente un disco de la cepa de patógeno proveniente de un cultivo de $48 \mathrm{~h}$ de crecimiento. Se retiraron las tapas de ambas placas y las bases conteniendo el patógeno se colocaron encima de las bases con el antagonista, de modo tal que los cultivos quedaran enfrentados, Cada set de placas enfrentadas se selló con parafilm y se incubó a $25{ }^{\circ} \mathrm{C}$. Como control se usaron pares con la cepa de $F$. graminearum en ambas placas. Se midió el diámetro de la colonia centrifuged, and the supernatant was filtered through a $0.45-\mu \mathrm{m}$ pore cellulose acetate filter.

Chitinolytic activity from the culture filtrates was measured according to the method of Mahadevan and Crawford (1997) with some modifications. Briefly, $90 \mu \mathrm{L}$ of culture filtrate and $10 \mu \mathrm{L}$ of a solution $0.18 \mathrm{mM}$ of p-nitrophenyl-N-acetyl- $\beta$-D-glucosaminide (Sigma, St. Louis, MO, USA) dissolved in sodium phosphate buffer $50 \mathrm{mM}, \mathrm{pH} 6.1$ were placed in wells of a flatbottom microtitre plate. The plate was incubated at $25^{\circ} \mathrm{C}$ for $24 \mathrm{~h}$ without agitation, and the reaction ended by the addition of $10 \mu \mathrm{L}$ of $\mathrm{NaOH} 1 \mathrm{M}$. Absorbance was read at $405 \mathrm{~nm}$ in an automatic Microplate Autoreader (Bio-tek Instruments, Winooski, VT, USA) against a blank of each sample, in which $\mathrm{NaOH}$ solution was added previous to incubation. The paranitrophenol ( $\mathrm{pNP}$ ) concentration obtained in each case was determined using a standard curve, one unit of enzyme was defined as the amount needed to release $1 \mu$ mole of $\mathrm{pNP}$ in one min. The assay was performed in triplicate per each strain.

Production of Volatile Antifungal Compounds. The production of volatile antifungal compounds was analyzed according to Arrarte et al. (2017) with modifications. Petri dishes containing PDA were inoculated centrally with a $5 \mathrm{~mm}$ mycelial agar plug from a non-sporulating, two-day-old PDA culture of each Trichoderma strain. At the same time, other plates containing PDA were inoculated in the same manner with a mycelial agar plug of the pathogen.

The lids of the dishes were removed, and the bases containing the pathogen were placed over those with the antagonist, in such a way that the cultures would be confronted. Each set of confronted dishes was sealed with Parafilm and incubated at $25^{\circ} \mathrm{C}$. As control, pairs with $F$. graminearum in both Petri dishes were used. The $F$. graminearum colony diameter was measured at day 5 , at the moment in which the pathogen covered all the control dish. Inhibition was expressed as the reduction percentage of the colony diameter compared with the control. The assay was performed in triplicate. Production of soluble antifungal compounds in liquid medium. This assay followed the methodology of Marques et al. (2018) with some modifications. The different Trichoderma strains were inoculated in flasks containing $50 \mathrm{~mL}$ of YES medium (yeast extract, $2 \%$; sacarose, $15 \%, \mathrm{pH}=6$ ) adding $1 \mathrm{~mL}$ of $1 \times 10^{6}$ conidia $\mathrm{mL}^{-1}$ suspension. The cultures were 
de $F$. graminearum al quinto día, momento en que la cepa del patógeno cubrió toda la placa control. La inhibición se expresó como el porcentaje de reducción del diámetro de la colonia respecto al control. El ensayo se realizó por triplicado.

Producción de compuestos antifúngicos solubles en medio líquido. Para este ensayo se siguió la metodología de Marques et al. (2018) con algunas modificaciones. Las distintas cepas de Trichoderma fueron inoculadas en matraces conteniendo $50 \mathrm{~mL}$ de medio YES $(\mathrm{pH}$ $=6$ ) agregando $1 \mathrm{~mL}$ de una suspensión de $1 \times 10^{6}$ conidios $\mathrm{mL}^{-1}$. Los cultivos fueron incubados a $25^{\circ} \mathrm{C}$, sin agitación, durante siete días. Al final de este lapso el sobrenadante del cultivo fue filtrado con filtros de poro $0.45 \mu \mathrm{m}$ para obtener una solución libre de células. El mismo fue incorporado a igual volumen de PDA doble concentración y vertido en placas de Petri, previo ajuste a $\mathrm{pH}=6$. Como control se prepararon placas incorporando igual volumen de medio YES sin inocular. Sobre cada placa se sembró un disco de micelio de $5 \mathrm{~mm}$ de diámetro del patógeno y se incubó a $25^{\circ} \mathrm{C}$. Al cabo de 4 días de incubación se midieron los diámetros de las colonias de $F$. graminearum y se compararon con los alcanzados en las placas control. La inhibición se expresó como el porcentaje de reducción del crecimiento de las colonias en las placas conteniendo los diferentes filtrados, con respecto a la media de los controles. El ensayo se realizó por triplicado.

\section{Cultivos Duales de Patógeno-Antagonista}

La capacidad de las distintas cepas de Trichoderma spp. de inhibirel crecimiento de Fusarium graminearum F224a, fue determinada mediante cultivos duales en placa de PDA a $25^{\circ} \mathrm{C}$. A partir de cultivos puros de tres días de crecimiento activo de los antagonistas y del patógeno sobre PDA se cortaron discos del borde de cada colonia con un sacabocado de $5 \mathrm{~mm}$ de diámetro. Se enfrentaron discos del patógeno con discos de los antagonistas en placas con PDA cada uno a $2.5 \mathrm{~cm}$ del centro de la placa. Como testigo se sembró en una placa un disco del patógeno en placa de PDA. Las placas se incubaron en estufa a $25^{\circ} \mathrm{C}$ y se midió el diámetro de cada colonia luego de 5 días, momento en el que la colonia del patógeno había cubierto la placa control. La capacidad antagónica de cada cepa se estableció de acuerdo con la siguiente escala: (1) el radio de cultivated at $25{ }^{\circ} \mathrm{C}$, without agitation for seven days. At the end of this interval, the culture supernatant was filtered with $0.45-\mu \mathrm{m}$ pore filters to obtain a cell-free solution, which was incorporated to an equal volume of PDA at double concentration and poured into Petri dishes previously adjusted to $\mathrm{pH}=6$. As control, PDA plates were prepared in the same manner but adding non-inoculated YES medium. On these dishes, a $5 \mathrm{~mm}$ mycelial agar plug of the pathogen was placed and incubated at $25{ }^{\circ} \mathrm{C}$. At the end of day 4 of incubation, $F$. graminearum colony diameters were measured and compared with those in control plates. Inhibition was expressed as colony growth reduction percentage in the Petri dishes containing different filtrates compared with the average growth in control plates. The assay was performed in triplicate.

\section{Dual Pathogen-Antagonist Cultures}

The capacity of the different Trichoderma spp. strains of inhibiting Fusarium graminearum F224a growth was determined by means of dual cultures in PDA Petri dishes at $25{ }^{\circ} \mathrm{C}$. Disks of 5 -mm from a three-day-old culture of antagonists and pathogen were cut from the border of each colony with a hole. puncher. Both pathogen and antagonist disks in Petri dishes with PDA were confronted, each one at $2.5 \mathrm{~cm}$ from the dish center. As control, a pathogen disk was sown in a Petri dish with PDA. The Petri dishes were incubated at $25{ }^{\circ} \mathrm{C}$, and the diameter of each colony was measured after five days, moment in which the pathogen colony had covered the control dish. The antagonistic capacity of each species was established according to the following scale: (1) the $F$. graminearum colony radius was greater than $2.5 \mathrm{~cm}$; (2) the $F$. graminearum radius was less than $2.5 \mathrm{~cm}$; (3) the Trichoderma spp. strain grew over all the Petri dish covering the $F$. graminearum colony. The assay was performed in triplicate for each case.

\section{Production Inhibition of the Pathogen Perithecia in the Pathogen-Antagonist Culture on Wheat Straw}

Five Trichoderma spp. strains of the Viride clade were selected to perform this assay. The selection was based on the results obtained in the dual culture study, in such a way to have representatives of all the defined categories in such assay. This study assessed 
la colonia de $F$. graminearum fue mayor que $2.5 \mathrm{~cm}$; (2) el radio de la colonia de $F$. graminearum fue menor que $2.5 \mathrm{~cm}$; (3) la cepa de Trichoderma spp. creció sobre toda la placa cubriendo la colonia de $F$. graminearum. El ensayo se realizó por triplicado para cada caso.

\section{Inhibición de la Producción de Peritecios del Patógeno en Cultivos Patógeno-Antagonista sobre Rastrojo de Trigo}

Cinco cepas de Trichoderma spp. del clado Viride fueron seleccionadas para realizar este ensayo. La selección se basó en los resultados obtenidos en el estudio de cultivos duales, de forma de tener representantes de todas las categorías definidas en dicho ensayo. En este estudio se evaluó la inhibición que cada cepa de Trichoderma spp. causó en la producción de peritecios por parte del patógeno sobre rastrojos de trigo (Bujold et al., 2001). Diez trozos de rastrojo de trigo de aproximadamente $7 \mathrm{~cm}$ de longitud, conteniendo un nudo cada uno, previamente esterilizados, se inocularon mediante inmersión por $1 \mathrm{~min}$ en $50 \mathrm{~mL}$ de una suspensión conjunta de conidios del patógeno y antagonista $\left(1 \times 10^{4}\right.$ conidias $\left.\mathrm{mL}^{-1}\right)$. Las suspensiones fueron preparadas a partir de cultivos en tubos de PDA inclinado utilizando suero fisiológico con Tween 80 al $0.1 \%$ para extraer los conidios. Los rastrojos inoculados se colocaron en placas de Petri conteniendo arena humedecida previamente esterilizada. Cada tratamiento de antagonista-patógeno fue realizado por triplicado. Tanto los rastrojos como la arena usados en este ensayo fueron esterilizados mediante dos sesiones en autoclave a $121^{\circ} \mathrm{C}$ durante 30 min en 2 días consecutivos. Como control se usaron rastrojos inoculados con una suspensión conteniendo únicamente conidios del patógeno. Las placas conteniendo los rastrojos tratados fueron incubadas a una temperatura de $25^{\circ} \mathrm{C}$ con ciclos de luz-oscuridad de $12 \mathrm{~h}$ cada uno para promover el desarrollo de los peritecios. La humedad de la arena de cada placa fue controlada cada cinco días y se agregó agua destilada estéril cuando fue necesario para mantener el peso inicial de cada placa. A los 40 días, todos los peritecios en la cara superior de los rastrojos de cada placa fueron contados bajo lupa. Los resultados se expresaron como porcentaje de inhibición respecto al promedio de la cantidad de peritecios presentes en las placas control. the inhibition in perithecium production by the pathogen on wheat straw caused by Trichoderma spp. strains (Bujold et al., 2001). Ten pieces of wheat straw of approximately $7 \mathrm{~cm}$ in length - each one with a knot - were previously inoculated by 1-min immersion in $50 \mathrm{~mL}$ of a suspension of conidia from the pathogen and one antagonist $\left(1 \times 10^{4}\right.$ conidia $\left.\mathrm{mL}^{-1}\right)$. The conidial suspensions were prepared from the cultures in the leaned PDA tubes using physiological serum with Tween 80 at $0.1 \%$ to extract conidia. The inoculated wheat straw was placed on Petri dishes containing humid sand previously sterilized. Each pathogenantagonist treatment was performed in triplicate. Both wheat straw and sand used in this assay were sterilized by two autoclave sessions at $121^{\circ} \mathrm{C}$ for $30 \mathrm{~min}$ in two consecutive days. As control, wheat straw inoculated with a suspension containing only pathogen conidia was used. The Petri dishes containing treated wheat straw were incubated at a temperature of $25^{\circ} \mathrm{C}$ with light-darkness cycles of $12 \mathrm{~h}$ to promote perithecia development. Sand humidity of each Petri dish was controlled each five days, and sterile distilled water was added when necessary to maintain initial weight of each Petri dish. At 40 days, all perithecia in the upper face of the wheat straw of each Petri dish were counted under a magnifying glass. The results were expressed as inhibition percentage with respect to the average of the perithecium amount found in the control Petri dishes.

\section{Correlation Between Antagonism Characteristics}

The correlation between chitinase and antifungal compounds (volatile and soluble) production, pathogen growth in dual cultures in Petri dishes and perithecia development on wheat straw, was determined by means of Spearman correlation coefficient, using the statistical program Infostat ${ }^{\circledR}$ (Di Rienzo, 2015).

\section{Statistical Analyses}

The results were analyzed with one-way Analysis of Variance (ANOVA) using Infostat ${ }^{\circledR}$ (Di Rienzo, 2015). Previous to the analysis, the percentage values were divided by 100 and transformed to arcsine square root. The comparison between averages was performed with Fisher's least significant difference (LSD) $(P<0.05)$. 


\section{Correlación entre Características de Antagonismo}

Se estudió el grado de correlación entre la producción de quitinasas y compuestos antifúngicos (volátiles y solubles), el crecimiento del patógeno en cultivo dual en placa y la formación de peritecios sobre rastrojo mediante la correlación de Spearman utilizando el programa estadístico Infostat ${ }^{\circledR}$ (Di Rienzo, 2015).

\section{Análisis Estadísticos}

Los resultados fueron analizados usando análisis de varianza de una vía con el programa Infostat ${ }^{\circledR}$ (Di Rienzo, 2015). Previo al análisis se realizó la transformación de los porcentajes a arcoseno de la raíz cuadrada del valor dividido 100. La comparación entre medias se realizó con el test LSD Fisher $(P<0.05)$.

\section{RESULTADOS Y DISCUSIÓN}

\section{Aislamiento e Identificación de Antagonistas}

Se obtuvieron 16 aislamientos de Trichoderma spp. provenientes de 20 muestras de rastrojo de trigo de diferentes zonas de cultivo, los cuales fueron identificados a nivel de especie mediante el análisis de las secuencias correspondientes a la región ITS1-ITS2 y parte del gen tefl $\alpha$. Mediante la comparación con secuencias correspondientes a cepas tipo depositadas en el GenBank y análisis filogenético se determinó que las cepas pertenecían a cinco especies diferentes. La identificación de cada una de las cepas se muestra en el Cuadro 1. Nueve cepas fueron identificadas como T. koningiopsis (57\%), tres como T. atroviride (19\%), dos cepas con T. longibrachiatum (12\%), una como T. afroharzianum y otra como T. rifaii.

\section{RESULTS AND DISCUSSION}

\section{Antagonist Isolation and Identification}

A total of 16 isolates of Trichoderma spp. from 20 samples of wheat straw from the different cultivation areas were identified at species level by the corresponding sequence analysis of the ITS1ITS2 region and part of the tefl $\alpha$ gene. By comparing with the corresponding sequences of the type strains deposited in the GenBank and by phylogenetic analysis, the strains were determined to belong to five different species. The identification of each one of the strains is shown in Table 1. Nine strains were identified as T. koningiopsis (57\%), three as T. atroviride (19\%), two as $T$. longibrachiatum (12\%), one as T. afroharzianum and another one as $T$. rifaii.

The phylogenetic tree obtained in such analysis included type strain sequences that showed similarity (98-100\%) with both sequences of the strains in study (Figure 1). The presence of three great groups with bootstrap values of $100 \%$ could be established. One of them corresponded to Viride clade where 12 of the isolated strains were included, of which nine were consistently grouped with T. koningiopsis GJS 93-20 (100\% bootstrap) type strain and three of them with T. atroviride CBS 142.95 (100\% bootstrap) which was also type strain.

Another group, in which the sequences corresponding to two strains (T35 and T4) were located, corresponded to the Harzianum clade. One of the sequences was grouped with $T$. afroharzianum GJS 04-186 (type strain) and the other one with T. rifaii DIS 355B (type strain), clearly separated from the type

Cuadro 1. Identificación de cepas Trichoderma spp. aisladas de rastrojo de trigo.

Table 1. Identification of Trichoderma spp. strains isolated from wheat straw.

\begin{tabular}{ll}
\hline Cepa / Strain & Especie / Species \\
\hline T1, T4, TR7, TR8, TR9, T10, T11, T12, T251a & T. koningiopsis \\
TmE, TmB, To & T. atroviride \\
TR4 & T. rifaii \\
T35 & T. afroharzianum \\
T2, T3 & T. longibrachiatum \\
\hline
\end{tabular}


El árbol filogenético obtenido en dicho análisis incluyó secuencias de cepas tipo que mostraron similitud (98-100\%) con ambas secuencias de las cepas en estudio (Figura 1). Se pudo constatar la presencia de tres grandes grupos con valores de boostrap de $100 \%$. Uno de ellos corresponde al clado Viride donde se incluyen 12 de las cepas aisladas, de las cuales strains of the other species in the same clade. The group formed by the T3 and T2 strains corresponded to the Longibrachiatum clade. The Uruguayan strains grouped with T. longibrachiatum ATCC 18648 type strain and were separated from $T$. bissettii UTHSC 08-2443 type strain, which was located in the same clade.

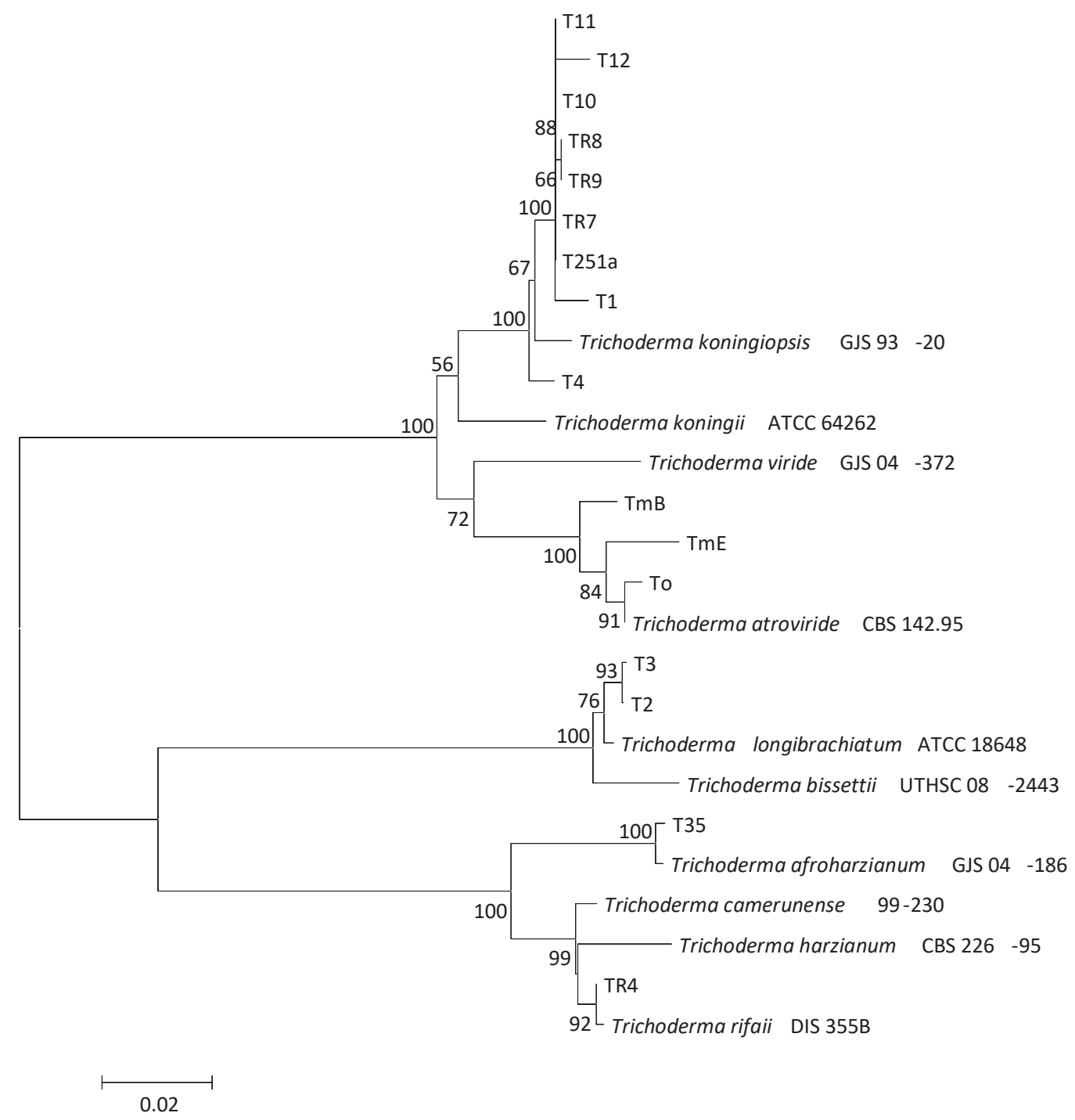

Figura 1. Árbol filogenético de las regiones ITS1-ITS2 y tef1 $\alpha$ de cepas nativas y cepas de referencia de Trichoderma spp. analizadas en forma concatenada. Para la construcción del árbol se usó NeighborJoining, las distancias evolutivas se calcularon mediante el método de Jukes-Cantor y los valores de bootstrap se calcularon para 1000 repeticiones. El análisis filogenético fue hecho con el programa MEGA 6.

Figure 1. Phylogenetic tree based on concatenated ITS1-ITS2 y tef1 $\alpha$ gene sequences of uruguayan Trichoderma spp. strains used in this work. Sequences from type strains retrieved from GenBank were included. The tree was constructed by Neighbour-Joining and evolutive distances were calculated by JukesCantor method. Bootstrap values were calculated from 1000 replications. Phylogenetic analysis was carried out with MEGA6. 
9 se agrupan consistentemente con la cepa tipo T. koningiopsis GJS 93-20 (100\% de boostrap) y tres de ellas con T. atroviride CBS 142.95 (100\% de boostrap) la cual es también una cepa tipo.

Otro grupo, en el que se ubican secuencias de dos cepas (T35 y T4), corresponde al clado Harzianum. Una de ellas se agrupa con la cepa tipo T. afroharzianum GJS 04-186 y la otra con T. rifaii DIS 355B quedando claramente separadas de cepas tipo de otras especies del clado. El grupo del que forman parte las cepas T3 y T2 corresponde al clado Longibrachiatum. Las cepas uruguayas agruparon con la cepa tipo T. longibrachiatum ATCC 18648, quedando separadas de la cepa tipo $T$. bissettii UTHSC 08-2443 la cual pertenece al mismo clado.

La mayoría de las cepas fueron identificadas como pertenecientes al clado Viride y dentro de éste a la especie T. koningiopsis. La presencia de esta especie ha sido descrita en regiones cálidas de América del Sur (Brasil y Perú) y en regiones más frías de América del Norte, en Canadá y este de Estados Unidos (Samuels, 2006). También dentro del mismo clado, otras tres cepas fueron identificadas como T. atroviride, especie que también ha sido reportada como cosmopolita (du Plessis et al., 2018). Dos de los aislamientos fueron identificados como T. longibrachiatum. Esta especie de amplia distribución geográfica, ha sido reportada como agente causal de infecciones localizadas y sistémicas en pacientes inmunodeprimidos o dializados (Druzhinina et al., 2008). Estas características imposibilitan el uso de esta especie como biocontrolador, especialmente si se plantea su uso en cultivos extensivos, por lo cual los aislamientos correspondientes no fueron considerados en este trabajo para ensayos posteriores. Los dos aislamientos restantes fueron identificados como T. afroharzianum y T. rifaii, pertenecientes al complejo de especies T. harzianum del clado Harzianum (Chaverri et al., 2015). Este complejo reúne por lo menos 14 especies entre las cuales se encuentra T. harzianum sensu stricto la cual da nombre al complejo. Un reciente trabajo de reclasificación de especies dentro de dicho complejo ha determinado que la especie $T$. harzianum sólo está presente en el hemisferio norte (Chaverri et al., 2015). Otras especies del clado, en cambio, tienen diferentes patrones de distribución geográfica. T. rifaii, por ejemplo, solamente ha sido encontrada en América del Sur y la especie T. afroharzianum ha sido reportada como de amplia distribución a nivel mundial. Por ello, el hallazgo de estas dos especies en Uruguay no resulta
Most of the strains were identified as T. koningiopsis within the Viride clade. The presence of this species has already been described in warm regions of South America (Brazil and Peru) and in colder regions of North America in Canada and eastern United States (Samuels, 2006). Additionally, within the same clade, other three strains were identified as T. atroviride - species that has also been reported as cosmopolitan (du Plessis et al., 2018). Two isolates were identified as $T$. longibrachiatum, a species of wide geographic distribution which has been reported as a causal agent of localized and systemic infections in immunodepressed or dialyzed patients (Druzhinina et al., 2008). These characteristics preclude the use of this species as a biocontrol agent, especially in extensive crops, and consequently, the strains of these species were not considered in further studies. The remaining isolates were identified as T. afroharzianum and $T$. rifaii, which belong to the species complex $T$. harzianum within the Harzianum clade (Chaverri et al., 2015). This complex gathers at least 14 species, including $T$. harzianum sensu stricto which gives its name to the complex. A recent work about species reclassification within such complex has determined that $T$. harzianum could only be found in the northern hemisphere (Chaverri et al., 2015). On the other hand, other species of the clade have different geographic distribution patterns. For example, T. rifaii, has only been found in South America, while T. afroharzianum has a worldwide distribution. Thus, finding these two species in Uruguay was not strange. To our knowledge, this is the first report of $T$. afroharzianum and T. rifaii in Uruguay.

\section{Characterization of Trichoderma spp. Strains}

Sensitivity to Tebuconazol. The sensitivity of Trichoderma spp. native strains to this fungicide was studied to determine the possibility of a joint application in an integrated disease management. The MIC values obtained for each strain were concordant between replicates. The strains of the Harzianum and Longibrachiatum clades, which represented $25 \%$ of the total, showed a MIC of $16 \mathrm{mg} \mathrm{L}^{-1}$ while those of the Viride clade were inhibited with $32 \mathrm{mg} \mathrm{L}^{-1}$ of the fungicide. The sensitivity to tebuconazole of Trichoderma spp. strains was very similar to that found for $F$. graminearum strains in a previous study 
extraño. Hasta donde sabemos este es el primer reporte de $T$. afroharzianum y $T$. rifaii en Uruguay.

\section{Caracterización de las Cepas de Trichoderma spp.}

Sensibilidad a Tebuconazol. La sensibilidad de las cepas nativas de Trichoderma spp. a este fungicida fue estudiada para determinar la posibilidad de una aplicación conjunta en un esquema de manejo integrado de la enfermedad. Los valores de CIM obtenidos para cada cepa fueron concordantes en las dos repeticiones del ensayo. Las cepas del clado Harzianum y del clado Longibrachiatum, que representan el $25 \%$ del total, presentaron una CIM de $16 \mathrm{mg} \mathrm{L}^{-1}$ mientras que las cepas del clado Viride fueron inhibidas con $32 \mathrm{mg} \mathrm{L}^{-1}$ del fungicida. La sensibilidad al tebuconazol de las cepas de Trichoderma spp. fue muy similar a la encontrada para las cepas de $F$. graminearum locales analizadas en un trabajo anterior (Umpiérrez et al., 2013), las cuales no han mostrado resistencia en condiciones de uso. A su vez, las cepas de Trichoderma aisladas en este trabajo, resultaron más sensibles al fungicida que cepas de origen europeo descritas por Hatvani et al. (2006), las cuales presentaron valores de CIM de $100 \mathrm{mg} \mathrm{L}^{-1}$ para tebuconazol. De acuerdo a los resultados se puede suponer que una aplicación conjunta del fungicida con el agente de biocontrol no sería efectiva, ya que podría comprometer la viabilidad del mismo.

Producción de xilanasas. Se determinó la capacidad de las cepas de Trichoderma spp. de producir xilanasas, enzimas asociadas a la capacidad de degradación de tejido vegetal y que facilitarían la degradación del rastrojo de trigo que actúa como soporte para el patógeno. Todas las cepas fueron capaces de producir xilanasas en las condiciones del ensayo (Figura 2). Se encontraron diferencias significativas $(P \leq 0.05)$ entre cepas de la misma especie del clado Viride, mientras que las cepas identificadas como T. longibrachiatum mostraron una actividad muy similar y relativamente baja. A su vez, la cepa con menor actividad fue TR4 identificada como $T$. rifaii perteneciente al clado Harzianum.

Producción de quitinasas. Para todas las cepas se estudió la capacidad de producir enzimas asociadas a la degradación de polímeros de la pared de hongos, tales como quitinasas y glucanasas. La producción de tales enzimas en forma extracelular se ha relacionado a la capacidad de micoparasitismo, mecanismo asociado a cepas de Trichoderma spp. con demostrada
(Umpiérrez et al., 2013), In turn, the Trichoderma strains isolated in this study resulted more sensitive to the fungicide than those of European origin described by Hatvani et al. (2006), which showed MIC values of $100 \mathrm{mg} \mathrm{L}^{-1}$ for tebuconazole. According to the results, a joint application of the fungicide with the biocontrol agent would not be effective since it could compromise its own viability.

Xylanase production. The capacity of Trichoderma spp. strains to produce xylanases was determined. Xylanases are enzymes associated to plant tissue degradation, which would facilitate the degradation of wheat straw that acts as support for the pathogen. All the strains were capable of producing xylanases in the assayed conditions (Figure 2). Significant differences $(P \leq 0.05)$ were found between strains of the Viride clade species, while the strains identified as $T$. longibrachiatum showed a very similar and relatively low activity. At the same time, the strain with less activity was TR4 identified as T. rifaii, which belongs to the Harzianum clade.

Chitinase production. The capacity of all Trichoderma strains to produce chitinases and glucanases, enzymes associated to fungal cell wall polymers degradation was evaluated in study. The extracellular production of such enzymes has been related to the capacity of mycoparasitism, mechanism associated to Trichoderma spp. with demonstrated biocontrol activity against fungal plant diseases (Matarese et al., 2012). The chitinolytic capacity of the different Trichoderma spp. strains are shown in Figure 3 and represents the average of three independent determinations performed at $25{ }^{\circ} \mathrm{C}$. In such conditions, all the strains produced extracellular chitinases. However, when the activity assay was performed at $40{ }^{\circ} \mathrm{C}$ for $30 \mathrm{~min}$ (protocol developed for xylanases), the activity values were very low in average and not detectable in some cases.

The strains belonging to the Viride clade showed different levels of activity with significant differences $(P \leq 0.05)$ in activity for strains of the same species, such as in the case of those of T. koningiopsis species. The strains of the Longibrachitum clade developed very similar activities with no significant differences $(P \leq 0.05)$ between them or with those that belonged to $T$. atroviride species of the Viride clade. The chitinolytic activity within the Harzianum clade was variable. The activity associated to the strain identified as $T$. afroharzianum was significantly $(P \leq 0.05)$ greater than that of the T. rifaii strain. 


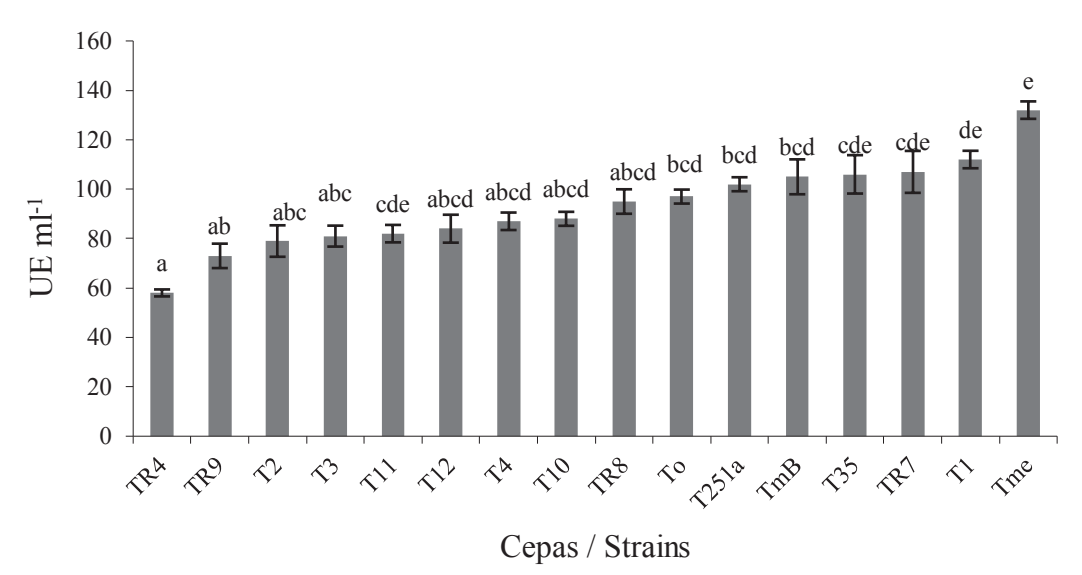

Figura 2. Xilanasas (UE $\mathrm{mL}^{-1}$ ) producidas por las cepas de Trichoderma spp. en presencia de xilano como única fuente de carbono. Las barras de error representan la desviación estándar de 3 repeticiones. Valores con letras distintas son significativamente diferentes según test de (LSD $P \leq 0.05)$.

Figure 2. Xylanases $\left(\mathrm{UE} \mathrm{mL}^{-1}\right)$ produced by Trichoderma spp. strains in presence of xylan a carbon source. Error bars represntatandard deviation of 3 repetitions. Distinct letters in the same column indicate significant differences (LSD $P \leq 0.05$ ).

actividad biocontroladora de enfermedades vegetales de origen fúngico (Matarese et al., 2012). La capacidad quitinolítica de las diferentes cepas de Trichoderma spp. se muestran en la Figura 3 y representan la media de tres determinaciones independientes, realizadas a $25{ }^{\circ} \mathrm{C}$. En dichas condiciones todas las cepas produjeron quitinasas extracelulares. Sin embargo, cuando el ensayo de actividad se realizó a $40{ }^{\circ} \mathrm{C}$ por media hora (protocolo desarrollado para xilanasas)
The results evidenced that all the strains in study can produce enzymes capable of degrading chitin, a fundamental activity to act as mycoparasite.

\section{Pathogen Growth Inhibition due to Volatile and Soluble Compounds in the Culture Medium}

Most of the Trichoderma spp. strains in the assay were capable of producing volatile and

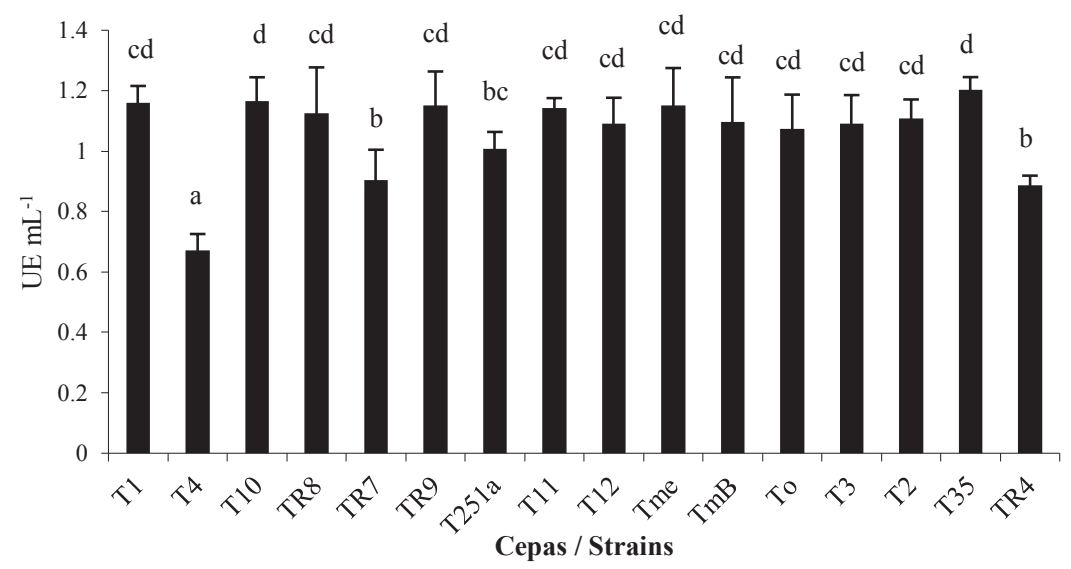

Figura 3. Actividad quitinolítica $\left(\mathrm{UE} \mathrm{mL}^{-1}\right)$ de las diferentes cepas de Trichoderma spp. Las barras de error representan la desviación estándar de 3 repeticiones. Valores con letras distintas son significativamente diferentes (LSD $P \leq 0.05$ ).

Figure 3. Chitinolytic activity (UE $\mathrm{mL}^{-1}$ ) produced of different Trichoderma spp. strains. Error bars represent standard deviation of 3 repetitions. Distinct letters in the same column indicate significant differences (LSD $P \leq 0.05$ ). 
los valores de actividad fueron muy bajos en promedio siendo no detectables en algunos casos.

Las cepas del clado Viride mostraron actividades dependientes de la cepa pudiéndose establecer diferencias significativas de actividad para cepas de la misma especie, como en el caso de las cepas de la especie T. koningiopsis. Las cepas del clado Longibrachitum desarrollaron actividades muy similares entre sí, sin diferencias significativas entre ellas ni con las pertenecientes a la especie $T$. atroviride del clado Viride. La actividad quitinilitica de las cepas del clado Harzianum fue significativamente diferente entre ellas, siendo la actividad asociada a la cepa identificada como T. afroharzianum significativamente mayor que la de la cepa de T. rifaii.

Los resultados evidenciaron que todas las cepas estudiadas podían producir enzimas capaces de degradar quitina, actividad fundamental para actuar como micoparásito.

\section{Inhibición del Crecimiento del Patógeno debido a Compuestos Volátiles y Solubles en el Medio de Cultivo}

La mayoría de las cepas de Trichoderma spp. ensayadas fueron capaces de producir metabolitos volátiles y solubles con actividad antifúngica contra el patógeno en estudio. Los mayores porcentajes de inhibición del patógeno (alrededor del 40\%) a causa de compuestos volátiles se lograron con las cepas T1 y T11 identificadas como T. koningiopsis, resultando en inhibiciones significativamente diferentes del resto $(P \leq 0.05)$ (Figura 4). Sin embargo, la inhibición alcanzada con otras cepas de la misma especie (TR8, TR7 y T251) fue muy leve, lo cual demuestra que la producción de metabolitos antifúngicos volátiles es una característica dependiente de la cepa. Varios compuestos volátiles han sido caracterizados como responsables de la actividad antifúngica de cepas de Trichoderma. Entre ellos se pueden citar compuestos aromáticos simples, pironas, terpenos volátiles e isocianatos (Stoppacher et al., 2010). La 6-pentyl-2Hpyran-2-ona (una pirona), compuesto volátil asociado con el aroma a coco característico de la especie T. atroviride (Garnica-Vergara et al., 2016), presenta actividad antifúngica. $\mathrm{Su}$ capacidad de inhibir in vitro del crecimiento de distintos hongos patógenos tales como Fusarium oxysporum f. sp. lycopersici y Rhizoctonia solani ha sido demostrada (Reino et al., soluble metabolites with antifungal activity against the pathogen of study. The greatest pathogen inhibition percentages (around 40\%) caused by volatile compounds were achieved with $\mathrm{T} 1$ and T11 strains identified as T. koningiopsis, which resulted significantly different $(P \leq 0.05)$ to the rest (Figure 4). Nevertheless, the inhibition achieved by other strains of the same species (TR8, TR7, and T251) was lower, which shows that the production of volatile antifungal metabolites is a strain dependent characteristic. Several volatile compounds have been characterized as responsible for the antifungal activity of the Trichoderma strains. Among them, simple aromatic compounds, pyrones, volatile terpenes, and isocyanates have been reported (Stoppacher et al., 2010). The 6-pentyl-2H-pyran-2-ona (one pyrone) - a volatile compound associated to coconut aroma, characteristic of $T$. atroviride (GarnicaVergara et al., 2016) - has antifungal activity. Its capacity of inhibiting in vitro growth of different fungal pathogens, such as Fusarium oxysporum f. sp. lycopersici and Rhizoctonia solani, has been demonstrated (Reino et al., 2008). According to these authors, the volatile compounds act at a distance empowering the localized action of the enzymes and the non-volatile antifungal compounds. The strains that inhibited the pathogen at a greater degree by producing soluble antifungal compounds were those that belonged to T. atroviride (TmE, TmB, and To) and T35 (T. afroharzianum). They produced more than $60 \%$ of inhibition, showing significant differences $(P \leq 0.05)$ with the rest of the strains. On the other hand, T1 (T. koningiopsis), T2, T3 (T. longibrachiatum) practically did not inhibit pathogen growth in this assay, showing values lower than $15 \%$. The strains of the genus Trichoderma produced a variety of secondary metabolites with antibacterial, antifungal, and antiviral activities. Among those that stand out are some non-ribosomal peptide synthesis formed from five to 20 amino acids, some of which do not form part of proteins, such as alpha aminoisobutyric acid and isovaline (Marik et al., 2018). These compounds receive the name of peptaibols and act at membrane level. Some of them are characteristic of determined species (Oh et al., 2005). For example, koninginins are produced by T. koninigiopsis (McMullin et al., 2017) while $T$. atroviride produces atroviridis and neoatroviridins (Komon-Zelazowska et al., 2007). Since these compounds are secondary metabolites, 


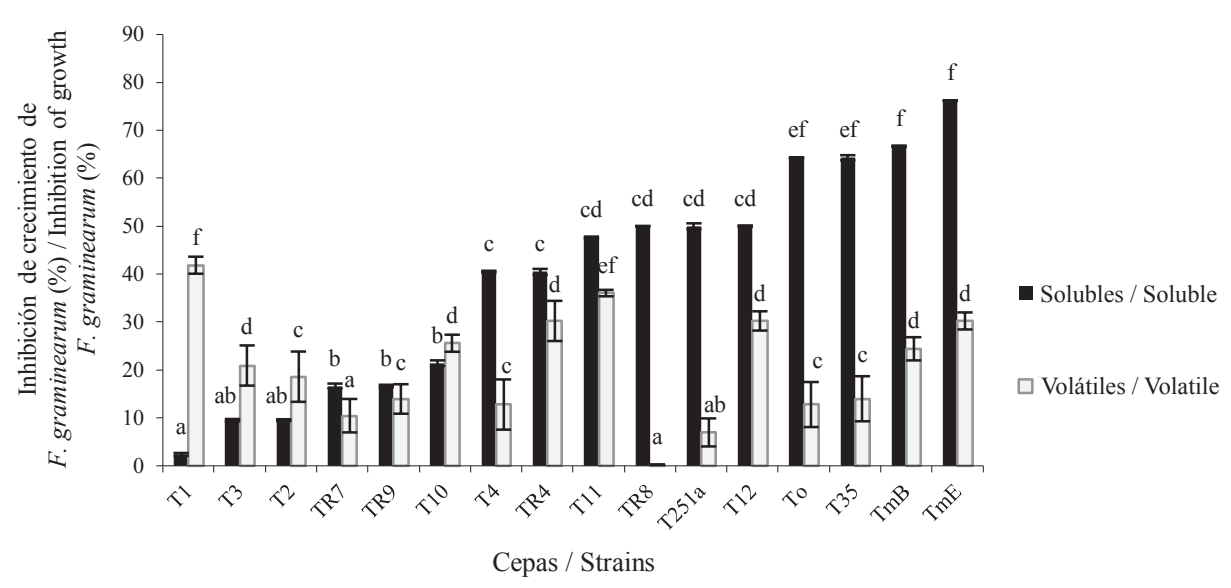

Figura 4. Inhibición del crecimiento de F. graminearum mediante metabolitos antifúngicos volátiles y solubles producidos por las cepas de Trichoderma spp. Las barras de error representan la desviación estándar de 3 repeticiones. Valores de cada categoría con letras distintas son significativamente diferentes (LSD $P \leq 0.05$ ).

Figure 4. Inhibition of F. graminearum growth by volatile and soluble antifungic compounds produced by Trichoderma spp. strains. Error bars represent standard deviation of 3 repetitions. Distinct letters in the same column indicate significant differences (LSD $P \leq 0.05$ ).

2008). Según estos autores los compuestos volátiles actuarían a distancia potenciando la acción localizada de las enzimas y los compuestos antifúngicos no volátiles. Las cepas que inhibieron en mayor grado al patógeno mediante la producción de compuestos antifúngicos solubles en el medio fueron las pertenecientes a la especie $T$. atroviride (TmE, TmB y To), junto a T35 (T. afroharzianum), con valores superiores al $60 \%$ de inhibición, presentando diferencias significativas con el resto de las cepas $(P \leq 0.05)$. Por su parte las cepas T1 (T. koningiopsis), T2, T3 (T. longibrachiatum) prácticamente no inhibieron el crecimiento del patógeno en este ensayo presentando valores inferiores al 15\%. Las cepas del género Trichoderma producen una variedad de metabolitos secundarios con actividad antibacteriana, antifúngica y antiviral. Entre ellos se destacan unos péptidos de síntesis no ribosómica formados por entre 5 y 20 aminoácidos, algunos de los cuales normalmente no forman parte de proteínas, tales como el ácido alfa aminoisobutírico y la isovalina (Marik et al., 2018). Estos compuestos reciben el nombre de peptaiboles y actúan a nivel de membrana. Algunos de ellos son característicos de determinadas especies (Oh et al., 2005). Por ejemplo, las koningininas son producidas por T. koninigiopsis (McMullin et al., 2017) mientras que $T$. atroviride produce atroviridinas y neoatroviridinas (Komon-Zelazowska et al., 2007). Dado que se trata de metabolitos secundarios, the production levels depend on the medium where the producing fungus develops, so the real role of these compounds in a specific pathosystem should be verified in situ. This study considered the production of soluble antimicrobial substances in YES medium, which was recommended by Paterson and Bridge (1994) to promote secondary metabolite production. Therefore, the results obtained in this study should be considered only as indicative of the antifungal activity of each strain. It would be important to corroborate its relationship with the antagonistic activity on wheat straw.

\section{Antagonist-Pathogen Dual Cultures}

Pathogen growth inhibition was evaluated confronting the different Trichoderma spp. strains in dual culture in PDA Petri dishes at $25{ }^{\circ} \mathrm{C}$. The pathogen colony radius in the confrontation zone with the antagonist was determined on day 5 of culture, moment at which the $F$. graminearum mycelium covered all the surface of the medium in the control Petri dishes. TmE, TmB, and To (T. atroviride) and TR8 (T. koningiopsis) produced the total inhibition of the pathogen, growing and sporulating over its mycelium. T2, T3, T4, TR4, T12, TR9, and T251 inhibited slightly the pathogen growth in the assayed conditions, and the rest of the strains showed an 
los niveles de producción dependen del medio donde se desarrolle el hongo productor, por lo cual el verdadero rol de estos compuestos en la actividad biocontroladora en un patosistema debe verificarse in situ. Este trabajo estudió la producción de sustancias antimicrobianas solubles en medio YES, medio recomendado por Paterson y Bridge (1994) para la potenciación de la producción de metabolitos secundarios. Por lo tanto, los resultados obtenidos, deberían ser considerados sólo como indicativos de actividad antifúngica de cada cepa frente al patógeno. Sería importante corroborar su relación con la actividad antagonista sobre rastrojo.

\section{Cultivos Duales de Patógeno-Antagonista}

Se evaluó la inhibición del crecimiento del patógeno enfrentado a las diferentes cepas de Trichoderma spp. en cultivo dual en placa en PDA a $25^{\circ} \mathrm{C}$. El radio de la colonia del patógeno en la zona de enfrentamiento con el antagonista, se determinó al quinto día de cultivo, momento en que el micelio de la cepa de $F$. graminearum cubrió toda la superficie del medio en las placas control. Las cepas TmE, TmB y To (T. atroviride) y TR8 (T. koningiopsis) produjeron la inhibición total del patógeno creciendo y esporulando sobre el micelio del mismo. Las cepas T2, T3, T4, TR4, T12, TR9 y T251 inhibieron levemente el crecimiento del patógeno en las condiciones ensayadas. El resto de las cepas presentó un comportamiento intermedio. La Figura 5 muestra el radio de la colonia del patógeno en intermediate behavior. Figure 5 shows the radius of the pathogen colony in the confrontation zone of dual cultures.

Figure 6 shows examples of dual cultures. In (a) the antagonist ( $T$. atroviride $\mathrm{TmE}$ ) grew over the pathogen, and in (b) the pathogen grew beyond the confrontation zone with $T$. koningiopsis $251 \mathrm{a}$, which is a weak antagonist in the assayed conditions.

Pathogen inhibition in dual cultures is one of the most utilized assays to study the biocontrol capacity of a microorganism. The extended use of this method is due to the simplicity of the assay. Nevertheless, it should be considered that it only provides indicative - non-definitive - results. In the first place, growth velocity of the two confronted microorganisms in the culture medium depended on the culture conditions, which are not always similar to those where the interaction would be expected to occur. In second place, the capacity of the biocontrol agent to inhibit the pathogen mostly depends on the inducible compound production or secondary metabolism products, so inhibition in the culture medium would not necessarily correspond to inhibition in the field (Mondino and Vero, 2006).

\section{Inhibition of Perithecia Production on Wheat Straw}

The production inhibition of perithecia by the pathogen on wheat straw was the definitive assay of

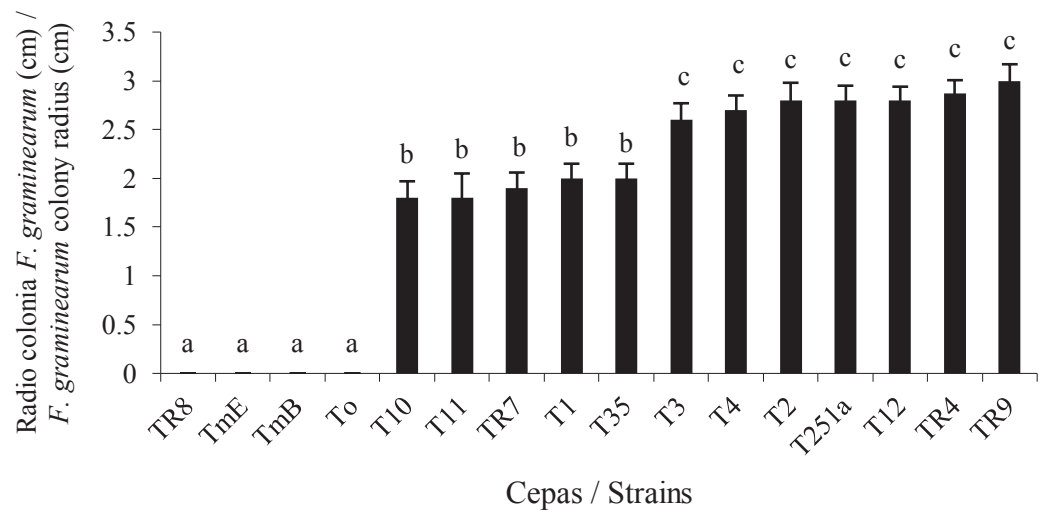

Figura 5. Radio (cm) de la colonia de $F$. graminearum en la zona de enfrentamiento con cada cepa de Trichoderma spp. Las barras de error representan la desviación estándar de 3 repeticiones. Valores con letras distintas son significativamente diferentes (LSD $P \leq 0.05$ ).

Figure 5. Radius of $\boldsymbol{F}$. graminearum colony facing Trichoderma spp. strains in dual cultures. Error bars represent standard deviation of 3 repetitions. Distinct letters in the same column indicate significant differences (LSD $P \leq 0.05$ ). 
la placa de cultivo dual en la zona de enfrentamiento con cada antagonista, luego de 5 días de cultivo.

En la Figura 6 se observan ejemplos de cultivos duales. En a) la colonia del antagonista (T. atroviride $\mathrm{TmE}$ ) creció sobre el patógeno y en b) el patógeno creció más allá de la zona de enfrentamiento con $T$. koningiopsis 251a, la cual es considerada un antagonista débil en las condiciones del ensayo.

La inhibición del patógeno en cultivos duales es una de las formas más utilizadas para estudiar la capacidad biocontroladora de un microorganismo. El uso extendido de este método se debe a la sencillez del ensayo. Sin embargo, debe tenerse en cuenta que el mismo aporta solamente resultados indicativos, no definitivos. En primer lugar, la velocidad de crecimiento de los dos microorganismos enfrentados depende de las condiciones de cultivo, las cuales, no siempre son similares a las del sitio donde se espera que ocurra la interacción. En segundo lugar, debe considerarse, que la capacidad del agente de biocontrol de inhibir al patógeno depende en gran medida de la producción de compuestos inducibles o productos del metabolismo secundario $\mathrm{y}$, por ello, la inhibición en medio de cultivo podría no corresponder a la inhibición en las condiciones de uso (Mondino y Vero, 2006).

\section{Inhibición de la Producción de Peritecios del Patógeno sobre Rastrojo de Trigo}

El ensayo de inhibición de la producción de peritecios sobre rastrojos es el ensayo definitivo de este estudio ya que reproduce en forma más fiel, lo que se espera que ocurra en el campo. Los ensayos anteriores son solamente indicativos del potencial de biocontrol this study since it reproduced - in the most faithful manner - what was expected to occur in field. The previous assays were only indicative of the potential biocontrol of the antagonists. All the Trichoderma spp. strains could significantly inhibit the production of perithecia on wheat straw (Figure 7).

An effective colonization of wheat straw by the different Trichoderma strains could also be observed (Figure 8). Of the strains selected, TmE and T11 produced higher levels of volatile antifungal compounds, which could contribute to control at distance. TmE, in turn, showed a significantly greater production of antifungal soluble compounds and also an elevated production of chitinases. The synergic action between the antimicrobial compounds and the hydrolytic enzymes have already been reported for Trichoderma spp. strains (Saravanakumar et al., 2017) and linked with the capacity of acting by mycoparasitism. In turn, TmE was the strain that produced greater xylanase levels, which could degrade the xylans in wheat straw, favoring its degradation. According to the results of this study, TmE identified as $T$. atroviride could be a good antagonist capable of colonizing wheat straw and inhibiting the development of $F$. graminearum mycelium and perithecia, thus contributing to Fusarium Head Blight control by decreasing the primary inoculum.

\section{Correlation Between Antagonism Characteristics}

A Spearman correlation analysis was performed with the results obtained for the strains from the Viride clade in the assays for chitinolytic activity, pathogen inhibition by volatile or soluble antifungal compounds,

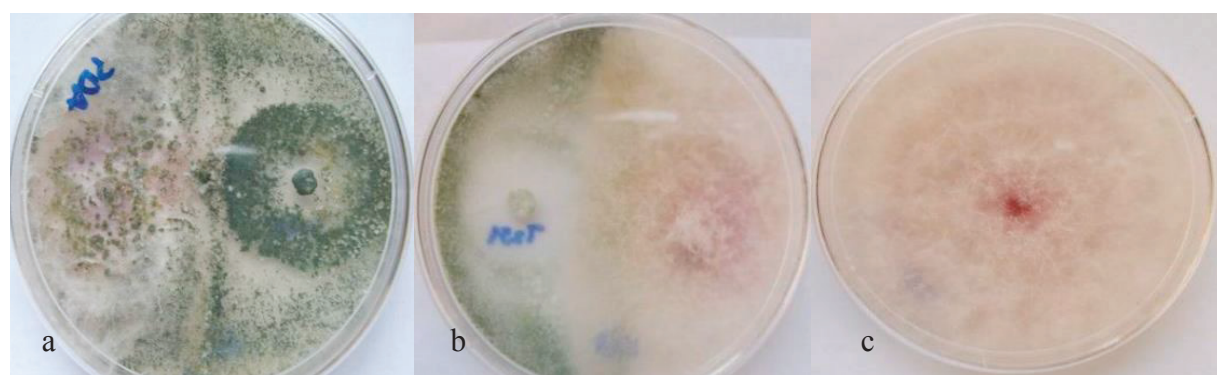

Figura 6. Ensayo de inhibición de $F$. graminearum en cultivo dual con cepas de Trichoderma spp.; a) TmE - F. Graminearum; b) T251a - F. graminearum y c) placa control.

Figure 6. Inhibition of $\boldsymbol{F}$. graminearum in dual cultures against Trichoderma spp.; a) TmE F. graminearum; b) T251a - F. graminearum y c) control. 
de los antagonistas. Todas las cepas de Trichoderma spp. ensayadas lograron inhibir significativamente la producción de peritecios por parte del patógeno sobre rastrojos de trigo (Figura 7).

Se observó una mayor producción de peritecios en el control y una colonización efectiva de los rastrojos por parte de las diferentes cepas de Trichoderma ensayadas (Figura 8). De las cepas seleccionadas, TmE y T11 demostraron mayor capacidad de producción de compuestos antifúngicos volátiles efectivos frente al patógeno, lo cual podría contribuir al control a distancia. La cepa TmE, a su vez, presentó una producción significativamente mayor de compuestos solubles antifúngicos y también una elevada producción de quitinasas. La acción sinérgica entre los compuestos antimicrobianos y las enzimas en la capacidad de biocontrol ya ha sido reportada previamente para cepas del género Trichoderma (Saravanakumar et al., 2017) y ha sido vinculada a la capacidad de actuar por micoparasitismo. A su vez, la cepa TmE fue la que produjo mayores niveles de xilanasas las cuales permitirían degradar xilanos presentes en el rastrojo favoreciendo la degradación del mismo. De acuerdo a los resultados de este trabajo la cepa $T m E$ identificada como $T$. atroviride podría ser un buen antagonista capaz de colonizar el rastrojo pathogen growth in dual cultures in plates, and the production of perithecia by the pathogen in dual cultures on wheat straw. Table 2 shows the results of the analysis. The main diagonal shows the correlation of variables with themselves (Value 1). The values above the main diagonal correspond to the probabilities associated to the null correlation hypothesis between the variables. The values located beneath the main diagonal show the correlation coefficients between the variables. Through these analyses, a significantly $(P \leq 0.05)$ strong positive correlation $(0.85)$ was determined between the pathogen growth in dual culture against strains from the Viride clade and the production of perithecia by the pathogen on wheat straw in the presence of those antagonists. Moreover, this study confirmed that the more an antagonist affected pathogen growth in the dual culture in Petri dish, the greater results in inhibition of perithecia production by the pathogen in wheat straw were observed in the presence of such antagonist. Likewise, a good negative correlation (-0.78) with a lower level of significance $(P=0.12)$ was obtained between chitinase production by the antagonists and the production of perithecia by the pathogen in wheat straw in presence of such antagonists. The chitinase production also showed a negative correlation (-0.80) with pathogen growth in the

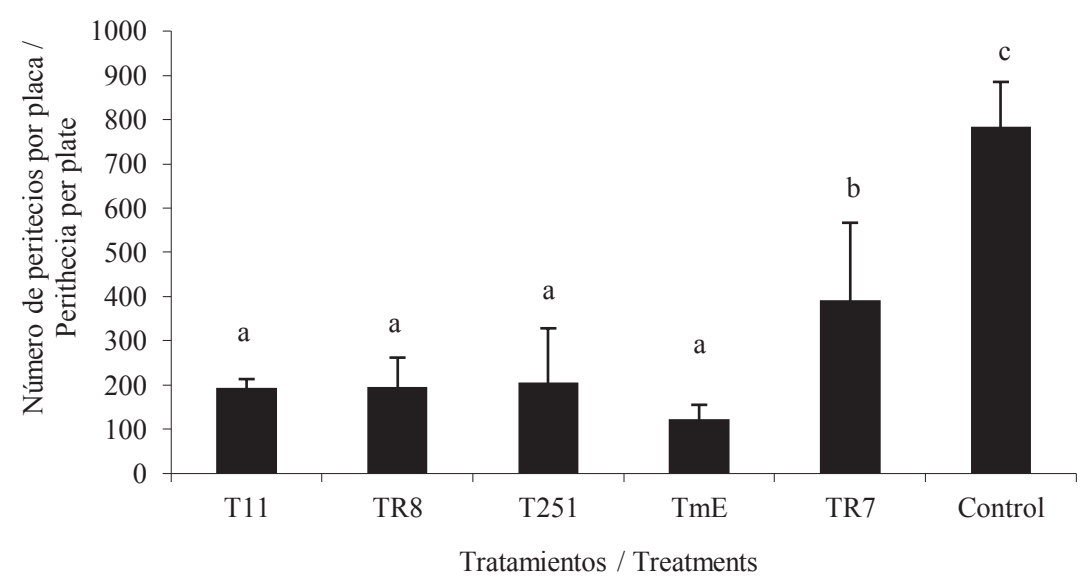

Figura 7. Peritecios producidos por el patógeno sobre rastrojos de trigo en presencia y en ausencia (control) de cepas de Trichoderma spp. del clado Viride. Las barras de error representan la desviación estándar de 3 repeticiones. Valores con letras distintas son significativamente diferentes según test de LSD con $P \leq 0.05$.

Figure 7. Perithecia produced by the pathogen on wheat straw y absence (a) and presence (b) of Trichoderma spp. from Viride clade. Error bars represent standard deviation of 3 repetitions. Distinct letters in the same column indicate significant differences (LSD $P \leq 0.05$ ). 


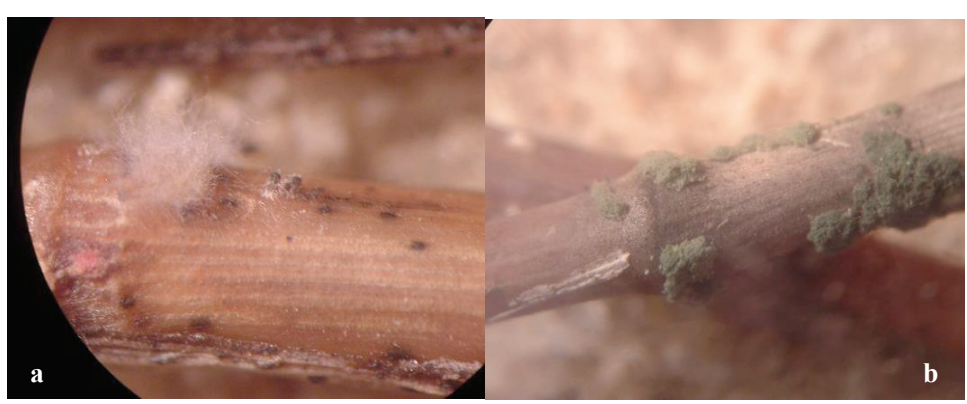

Figura 8. Crecimiento de $\boldsymbol{F}$. graminearum sobre rastrojos de trigo en ausencia (a) y en presencia de T. atroviride TmE. En (a) se observan los peritecios bajo microscopio óptico con aumento 50X.

Figure 8. Growth of $F$. graminearum on wheat straw in absence (a) and presence (b) of $T$. atroviride TmE. Black points in a) are $F$. graminearum perithecia observed under optical microscope with a magnification of $50 \mathrm{X}$.

de trigo e inhibir la formación de micelio y peritecios de $F$. graminearum, contribuyendo así al control de la fusariosis de espiga mediante la disminución del inóculo primario.

\section{Correlación entre Características de Antagonismo}

Se realizó el análisis de correlación de Spearman para los resultados obtenidos con las cinco cepas del clado Viride en los ensayos de actividad quitinilítica, inhibición del patógeno por compuestos antifúngicos volátiles o solubles, crecimiento del patógeno en cultivos duales en medio de cultivo y formación de peritecios del patógeno en cultivos duales sobre rastrojo de trigo. Los resultados del análisis se observan en el Cuadro 2. La diagonal principal dual culture in the presence of the different Trichoderma spp. strains. In this case a greater chitinase production was correlated with lower pathogen growth in the dual culture $(P=0.10)$. The inhibition of the pathogen by volatile and soluble antifungal compounds produced by the Trichoderma spp. strains did not show a significant correlation with the inhibition of perithecium production by the pathogen or the antagonist activity in the dual culture. According to these results, only would the antagonism study in dual culture in Petri dish and the chitinase production in presence of the pathogen walls be necessary to determine the potential of the Trichoderma strains as biocontrol agents of $F$. graminearum production of perithecia on wheat straw, making it unnecessary to perform the rest of the assays to estimate such potential.

Cuadro 2. Correlación entre actividades de las cepas de Trichoderma spp. asociadas al control de F. Graminearum.

Table 2. Correlation between different activities of Trichoderma spp. strains associated to F. graminearum control.

\begin{tabular}{|c|c|c|c|c|c|}
\hline \multirow{2}{*}{ Actividades / Activities } & \multicolumn{5}{|c|}{ Actividades / Activities } \\
\hline & $\mathrm{a}$ & $\mathrm{b}$ & $\mathrm{c}$ & $\mathrm{d}$ & e \\
\hline $\mathrm{a}$ & 1 & 0.10 & 0.93 & 0.31 & 0.05 \\
\hline $\mathrm{b}$ & -0.8 & 1 & 0.72 & 0.14 & 0.12 \\
\hline $\mathrm{c}$ & -0.05 & $0-22$ & 1 & 0.72 & 0.23 \\
\hline$d$ & -0.57 & 0.75 & 0.22 & 1 & 0.22 \\
\hline e & 0.85 & -0.78 & -0.6 & -0.67 & 1 \\
\hline
\end{tabular}

$\overline{\mathrm{a}}=$ crecimiento de $F$. graminearum en cultivos duales; $\mathrm{b}=$ producción de quitinasas; c = inhibición de $F$. graminearum por compuestos antifúngicos volátiles; d = inhibición de $F$. graminearum por compuestos antifúngicos solubles; e = producción de peritecios de $F$. graminearum . $\mathrm{a}=F$. graminearum growth in dual cultures; $\mathrm{b}=$ chitinases production; $\mathrm{c}=$ inhibition of $F$. graminearum growth by volatile antifungal compounds; d = inhibition of $F$. graminearum growth by soluble antifungal compounds; e = production of perithecia by $F$. graminearum . 
muestra los valores de correlación de una variable consigo misma (valor 1). Los valores por encima de la diagonal principal corresponden a las probabilidades asociadas a la prueba de hipótesis de correlación nula entre las variables. Los valores ubicados por debajo de la diagonal principal muestran los coeficientes de correlación entre las variables. Mediante este análisis se determinó una fuerte correlación positiva (0.85) y significativa $(P \leq 0.05)$ entre el crecimiento del patógeno enfrentado a las distintas cepas del clado Viride en cultivo dual y la producción de peritecios por parte del patógeno en rastrojo en presencia de dichos antagonistas. Se constató que cuanto más afecta un antagonista el crecimiento del patógeno en cultivo dual en placa, mayor resulta la inhibición de la producción de peritecios en rastrojos en presencia de dicho antagonista. A su vez, se demostró una buena correlación negativa (-0.78) con un menor nivel de significancia $(P=0.12)$ entre la producción de quitinasas por parte de los antagonistas y la producción de peritecios del patógeno en rastrojos en presencia de dichos antagonistas. La producción de quitinasas también mostró correlación negativa $(-0.80)$ con el crecimiento del patógeno en cultivo dual en presencia de las diferentes cepas de Trichoderma spp. En este caso, una mayor producción de quitinasas se correlacionó con un menor crecimiento del patógeno en cultivo dual $(\mathrm{P}=0.10)$. Se pudo observar, que la inhibición del patógeno por compuestos antifúngicos volátiles y solubles producidos las cepas de Trichoderma spp. no mostró correlación significativa con la inhibición de producción de peritecios en rastrojo ni con la actividad de los antagonistas en cultivo dual. De acuerdo con estos resultados, el estudio del antagonismo en cultivo dual en placa y la producción de quitinasas en presencia de paredes del patógeno serían suficientes para determinar el potencial de cepas de Trichoderma como biocontrolador de la producción de peritecios de $F$. graminearum en rastrojo de trigo no siendo necesario la realización de los restantes ensayos para estimar dicho potencial.

\section{CONCLUSIONES}

A partir de muestras de rastrojos de trigo fue posible aislar cepas de Trichoderma spp. capaces

\section{CONCLUSIONS}

This study obtained native Trichoderma spp. strains capable of colonizing wheat straw and inhibiting the development of perithecia by the pathogen. Their use could be effective in controlling the primary inoculum and thus decrease the risks of wheat fusarium head bright appearance. All the strains obtained exhibited one or several activities that could be related to their potential as biocontrol agents. However, the correlation studies among the different activities and perithecium inhibition in wheat straw evidenced that dual culture and chitinase production performance are characteristics related clearly with the antagonist performance. The selected T. atroviride TmE strain stood out for its antagonist potential and its capacity to produce xylanases linked to the colonization and degradation of wheat straw that serves as pathogen support.

-End of english version-

de colonizar dicho residuo e inhibir la formación de peritecios por parte del patógeno, de forma de controlar el inóculo primario y así disminuir los riesgos de aparición de fusariosis de espiga en trigo. Todas las cepas obtenidas exhibieron una o varias actividades que podrían relacionarse con su potencial como agente de biocontrol. Sin embargo, los estudios de correlación entre las diferentes actividades y la inhibición de peritecios en rastrojo evidenciaron que el desempeño en cultivo dual y la producción de quitinasas son características que se relacionan claramente con el desempeño del antagonista. La cepa seleccionada, T. atroviride TmE, se destacó por su potencial antagonista y por su capacidad de producir xilanasas las cuales se vinculan a la capacidad de colonización y degradación del rastrojo que sirve de soporte al patógeno. 


\section{REFERENCIAS / REFERENCES}

Amarasinghe, C. C., L. Tamburic-Ilincic, J. Gilbert, A. L. BrûléBabel, and W. G. Dilantha Fernando. 2013. Evaluation of different fungicides for control of Fusarium head blight in wheat inoculated with $3 \mathrm{ADON}$ and $15 \mathrm{ADON}$ chemotypes of Fusarium graminearum in Canada. Can. J. Plant Pathol. 35: 200-208. doi: https://doi.org/10.1080/07060661.2013.773942.

Arrarte, E., G. Garmendia, C. Rossini, M. Wisniewski, and S. Vero. 2017. Volatile organic compounds produced by Antarctic strains of Candida sake play a role in the control of postharvest pathogens of apples. Biol. Control. 109: 14-20. doi: https://doi.org/10.1016/j.biocontrol.2017.03.002.

Bujold, I., T. C. Paulitz, and O. Carisse. 2001. Effect of Microsphaeropsis sp. on the production of perithecia and ascospores of Gibberella zeae. Plant Dis. 85: 977-984. doi: https://doi.org/10.1094/PDIS.2001.85.9.977.

Carbone, I. and L. M. Kohn. 1999. A method for designing primer sets for speciation studies in filamentous ascomycetes. Mycologia 91: 553-556. doi: https://doi.org/10.2307/3761358.

Casa, R. T., E. M. Reis, M. M. C. Blum, A. Bogo, O. Scheer e T. Zanata. 2004. Danos causados pela infecção de Gibberella zeae em trigo. Fitopatol. Bras. 29: 289-293. doi: https://doi. org/10.1590/S0100-41582004000300008.

Chaverri, P., F. Branco-Rocha, W. Jaklitsch, R. Gazis, T. Degenkolb, and G. J. Samuels. 2015. Systematics of the Trichoderma harzianum species complex and the reidentification of commercial biocontrol strains. Mycologia 107: 558-590. doi: https://doi.org/10.3852/14-147.

Dill-Macky, R. and R. K. Jones. 2000. The effect of previous crop residues and tillage on Fusarium head blight of wheat. Plant Disease. 84: 71-76. doi: https://doi.org/10.1094/ PDIS.2000.84.1.71.

Di Rienzo, J. A., F. Casanoves, M. G. Balzarini, L. Gonzalez, M. Tablada, and C. W. Robledo. 2015. Software para análisis estadístico InfoStat. Grupo InfoStat, FCA, Universidad Nacional de Córdoba. URL http://www.infostat.com.ar. Argentina.

Druzhinina, I. S., M. Komon-Zelazowska, L. Kredics, L. Hatvani, Z. Antal, T. Belayneh, and C. P. Kubicek. 2008. Alternative reproductive strategies of Hypocrea orientalis and genetically close but clonal Trichoderma longibrachiatum, both capable of causing invasive mycoses of humans. Microbiology 154: 3447-3459. doi: https://doi.org/10.1099/mic.0.2008/021196-0.

du Plessis, I. L., I. S. Druzhinina, L. Atanasova, O. Yarden, and K. Jacobs. 2018. The diversity of Trichoderma species from soil in South Africa, with five new additions. Mycologia 110: 559-583. doi: https://doi.org/10.1080/00275514.2018.1463059.

Edwards, S. G., S. R. Pirgozliev, M.C. Hare, and P. Jenkinson. 2001. Quantification of trichothecene-producing Fusarium species in harvested grain by competitive PCR to determine efficacies of fungicides against Fusarium head blight of winter wheat. Appl. Environ. Microbiol. 67: 1575-1580. doi: https://doi.org/10.1128/AEM.67.4.1575-1580.2001

Felsenstein, J. 1985. Confidence limits on phylogenies: An approach using the bootstrap. Evolution 39: 783-791. doi: https://doi.org/10.2307/2408678.
Garnica-Vergara, A., S. Barrera-Ortiz, E. Muñoz-Parra, J. Raya-González, A. Méndez-Bravo, L. Macías-Rodríguez, L. F. Ruiz-Herrera, and J. López-Bucio. 2016. The volatile 6-pentyl-2H-pyran-2-one from Trichoderma atroviride regulates Arabidopsis thaliana root morphogenesis via auxin signaling and ethylene insensitive 2 functioning. New Phytol. 209: 1496-1512. doi: https://doi.org/10.1111/ nph.13725.

Garmendia, G. and S. Vero. 2016. Occurrence and biodiversity of Aspergillus section Nigri on 'Tannat'grapes in Uruguay. Int. J. Food Microbiol. 216: 31-39. doi: https://doi.org/10.1016/j. ijfoodmicro.2015.08.020.

Hatvani, L., Z. Antal, L. Manczinger, A. Szekeres, I. S. Druzhinina, C. P. Kubicek, A. Nagy, E. Nagy, C. Vágvölgyi, and L. Kredics. 2007. Green mold diseases of Agaricus and Pleurotus spp. are caused by related but phylogenetically different Trichoderma species. Phytopathology 97: 532-537. doi: https://doi.org/10.1094/PHYTO-97-4-0532.

Inch, S. and J. Gilbert. 2007. Effect of Trichoderma harzianum on perithecial production of Gibberella zeae on wheat straw. Biocon. Sci. Technol. 17: 635-646. doi: https://doi. org/10.1080/09583150701408865.

Jaklitsch, W. M. and H. Voglmayr. 2015. Biodiversity of Trichoderma (Hypocreaceae) in Southern Europe and Macaronesia. Stud. Mycol. 80: 1-87. doi: https://doi. org/10.1016/j.simyco.2014.11.001.

Jukes, T. H. and C. R. Cantor. 1969. Evolution of protein molecules. pp. 21-132. In: H. N. Munro (ed.). Mammalian protein metabolism. Academic Press. New York, NY, USA. doi: https://doi.org/10.1016/B978-1-4832-3211-9.50009-7.

Komon-Zelazowska, M., T. Neuhof, R. Dieckmann, H. von Döhren, A. Herrera-Estrella, C. P. Kubicek, and I. S. Druzhinina. 2007. Formation of atroviridin by Hypocrea atroviridis is conidiation associated and positively regulated by blue light and the G protein GNA3. Eukaryotic Cell 6: 2332-2342. doi: https://doi.org/10.1128/EC.00143-07.

Mahadevan, B. and D. L.Crawford. 1997. Properties of the chitinase of the antifungal biocontrol agent Streptomyces lydicus WYEC108. Enz. Microbial Technol. 20: 489-493. doi: https://doi.org/10.1016/S0141-0229(96)00175-5.

Marik, T., C. Tyagi, G. Racić, D. Rakk, A. Szekeres, C. Vágvölgyi, and L. Kredics. 2018. New 19-residue peptaibols from Trichoderma clade Viride. Microorganisms 6:85. doi: https://doi.org/10.3390/microorganisms6030085.

Marques, E., I. Martins, and S. C. Marques de Mello. 2018. Antifungal potential of crude extracts of Trichoderma spp. Biota Neotrop. 18: e20170418. doi: https://oi. org/10.1590/1676-0611-bn-2017-0418.

Matarese, F., S. Sarrocco, S. Gruber, V. Seidl-Seiboth, and G. Vannacci. 2012. Biocontrol of Fusarium head blight: interactions between Trichoderma and mycotoxigenic Fusarium. Microbiology 158: 98-106. doi: https://doi. org/10.1099/mic.0.052639-0.

Mazzilli, S. R., C. M. Becerril-Pérez y O. Ernst. 2011. Una alternativa para optimizar el uso de fungicidas para controlar fusariosis de espiga en trigo. Agrociencia 15: 6068. doi: https://doi.org/10.2477/vol15iss2pp60-68. 
McMullin, D. R., J. B. Renaud, T. Barasubiye, M. W. Sumarah, and J. D. Miller. 2017. Metabolites of Trichoderma species isolated from damp building materials. Can. J. Microbiol. 63: 621-632. doi: https://doi.org/10.1139/cjm-2017-0083.

Mondino, P. y S. Vero. 2006. Control biológico de patógenos en plantas. Udelar. CSEP. Montevideo, Uruguay. ISBN: 997-40035-98.

Oh, S. U., B. S. Yun, S. J. Lee, and I. D. Yoo. 2005. Structures and biological activities of novel antibiotic peptaibols neoatroviridins AD from Trichoderma atroviride F80317. J. Microbiol. Biotechnol. 15: 384-387.

Palazzini, J., P. Roncallo, R. Cantoro, M. Chiotta, N. Yerkovich, S. Palacios, V. Echenique, A. Torres, M. Ramírez, P. Karlovsky, and S. Chulze. 2018. Biocontrol of fusarium graminearum sensu stricto, reduction of deoxynivalenol accumulation and phytohormone induction by two selected antagonists. Toxins 10: 88-98. doi: https://doi.org/10.3390/toxins10020088.

Paterson R. R. M. and P. D. Bridge. 1994. Biochemical techniques for filamentous fungi. CaB International. Wallingford, UK. ISBN-13: 978-0851988993.

Pestka, J. J. and A. T. Smolinski. 2005. Deoxynivalenol: toxicology and potential effects on humans. J. Toxicol. Environ. Health Part B: Critical Rev. 8: 39-69. doi: https:// doi.org/10.1080/10937400590889458.

Pereyra, S. 2003. Prácticas culturales para el manejo de la fusariosis de la espiga. pp. 1-9. In: Jornada técnica de cultivos de invierno. INIA. La Estanzuela, Colonia, Uruguay.

Reino, J. L., R. F. Guerrero, R. Hernández-Galán, and I. G. Collado. 2008. Secondary metabolites from species of the biocontrol agent Trichoderma. Phytochem. Rev. 7: 89-123. doi: https://doi.org/10.1007/s11101-006-9032-2.

Saitou, N. and M. Nei. 1987. The neighbor-joining method: a new method for reconstructing phylogenetic trees. Mol. Biol. Evol. 4: 406-425. doi: https://doi.org/10.1093/oxfordjournals. molbev.a040454.

Samuels G. J. 2006. Trichoderma: Systematics, the sexual state, and ecology. Phytopathology 96: 195-206. doi: https://doi. org/10.1094/PHYTO-96-0195.

Samuels, G. J., C. Suarez, K. Solis, K. A. Holmes, S. E. Thomas, A. Ismaiel, and H. C. Evans. 2006. Trichoderma theobromicola and T. paucisporum: Two new species isolated from cacao in South America. Mycol. Res. 110: 381-392. doi: https://doi. org/10.1016/j.mycres.2006.01.009.
Saravanakumar, K., Y. Li, C. Yu, Q. Wang, M. Wang, J. Sun, J. Gao, and J. Chen. 2017. Effect of Trichoderma harzianum on maize rhizosphere microbiome and biocontrol of Fusarium stalk rot. Sci. Rep.7: 1771. doi: https://doi.org/10.1038/ s41598-017-01680-w.

Schisler, D. A., N. I. Khan, and M. J. Boehm. 2002. Biological control of Fusarium head blight of wheat and deoxynivalenol levels in grain via use of microbial antagonists. pp. 53-69. In: J. W. DeVries, M. W. Trucksess, and L. S. Jackson (eds.). Mycotoxins and food safety. Advances in experimental medicine and biology, vol 504. Springer. Boston, MA, USA. Online ISBN: 978-1-4615-0629-4. doi: https:/doi. org/10.1007/978-1-4615-0629-4_6.

Stoppacher, N., B. Kluger, S. Zēilinger, R. Krska, and R. Schuhmacher. 2010. Identification and profiling of volatile metabolites of the biocontrol fungus Trichoderma atroviride by HS-SPME-GC-MS. J. Microbiol. Methods 81: 187-193. doi: https://doi.org/10.1016/j.mimet.2010.03.011.

Tamura, K., G. Stecher, D. Peterson, A. Filipski, and S. Kumar. 2013. MEGA6: Molecular evolutionary genetics analysis version 6.0. Mol. Biol. Evol. 30: 2725-2729. doi: https://doi. org $/ 10.1093 / \mathrm{molbev} / \mathrm{mst} 197$.

Umpiérrez, M., G. Garmendia, M. Cabrera, S. Pereyra, and S. Vero. 2013. Diversity of pathogen populations causing Fusarium head blight of wheat in Uruguay. pp. 31-44. In: T. Alconada and S. Schulze (eds.) Fusarium head blight in Latin America. Springer. Dordrecht. Print ISBN: 978-94007-7090-4.

Vero, S., G. Garmendia, M. B. Gonzalez, O. Bentancur, and M. Wisniewski. 2013. Evaluation of yeasts obtained from Antarctic soil samples as biocontrol agents for the management of postharvest diseases of apple (Malus $\times$ domestica). FEMS Yeast Res. 13: 189-199. doi: https://oi. org/10.1111/1567-1364.12021.

Villar, A., O. Ernst, M. Cadenazzi, S. Vero, S. Pereyra, N. Altier, D. Chouhy, F. Langone y C. A. Pérez. 2019. Efecto de la secuencia de cultivos sobre la población nativa de Trichoderma spp. en agricultura sin laboreo. Agrociencia Uruguay 23: 18-27. doi: http://dx.doi.org/10.31285/agro.23.1.5.

White, T. J., T. Bruns, S. Lee, J. Taylor, M. A. Innis, D. H. Gelfand, and J. Sninsky. 1990. Amplification and direct sequencing of fungal ribosomal RNA genes for phylogenetics. pp. 315-322. In: M. A. Innis, D. H. Gelfand, J. J. Snisky, and T. J. White (eds.). PCR protocols: A guide to methods and applications. Academic Press. San Diego, CA, USA. ISBN-13: 9780123721815. 